\title{
Palaeobotanical and biomarker evidence for Early Permian (Artinskian) wildfire in the Rajmahal Basin, India
}

\author{
Srikanta Murthy ${ }^{1 *}$, Vinod Atmaram Mendhe ${ }^{2}$, Dieter Uhl ${ }^{3}$, Runcie Paul Mathews ${ }^{1}$, Vivek Kumar Mishra ${ }^{2}$ and
} Saurabh Gautam ${ }^{1}$

\begin{abstract}
This study provides a combined analysis on the palynology, fossil charcoal and biomarkers of the subsurface coal deposits from a borehole RMB \#2 drilled at the Dhulia Coal Block, Rajmahal Basin, India, in attempts to establish the chronology of sedimentation and to propose palaeobotanical as well as geochemical evidence for the occurrence of wildfires in these sediments. The palynological investigation suggests a Scheuringipollenites barakarensis palynoassemblage from the lower Barakar Formation, dated as Artinskian (Early Permian) in age. This assemblage reveals the dominance of Glossopteridales and sub-dominance of taxa belonging to Cordaitales and Coniferales. Fossil charcoal in sediments is usually recognized as a direct indicator for the occurrence of palaeo-wildfires. More data involving the anatomical features of fossil charcoal analyzed by Field Emission Scanning Electronic Microscope broaden our knowledge on Early Permian wildfires from the peninsula of India. The studied macroscopic charcoal fragments exhibit anatomical details such as homogenized cell walls, uniseriate simple and biseriate alternate pitting on tracheid walls and rays of varying heights pointing to a gymnospermous wood affinitity. The excellent preservation of charcoal fragments, shown by their large sizes and almost unabraded edges, suggests a parautochthonous origin. The embedded biomarker study performed for charcoal sediments and its characterization demonstrate the presence of $n$-alkanes, isoprenoids, terpenoids and aromatic compounds. A bimodal distribution pattern of $n$-alkanes with a $C_{\max }$ at $n-C_{25}$ is identified. Diterpenoids and pentacyclic terpenoids are identified, indicating the input of an early conifer vegetation and bacterial activity, respectively. The identified polyaromatic hydrocarbon (PAH) compounds, together with the charcoal fragments, clearly suggest that repeated wildfire events occurred during the deposition of these Artinskian sediments in the Rajmahal Basin.
\end{abstract}

Keywords: Palaeo-wildfire, Palynology, Fossil charcoal, Biomarker, Barakar Formation, Rajmahal Basin

\section{Introduction}

The Rajmahal Basin contains an excellent succession of the upper Gondwana sediments in India, which is represented by the Dubrajpur Formation (Lower Triassic to Lower Cretaceous) and the Rajmahal Formation (Lower Cretaceous). The Rajmahal Formation includes traps and intertrappean beds. These intertrappean sediments

\footnotetext{
* Correspondence: srikanta_murthy22@rediffmail.com

'Birbal Sahni Institute of Palaeosciences, 53, University Road, Lucknow 226007, India

Full list of author information is available at the end of the article
}

crop out all over the Rajmahal Basin, except in its west part (Fig. 1). The Intertrappean beds have been investigated in detail because of their rich megaplant fossil accumulation of the Ptilophyllum flora and other assemblages of ferns, conifers and cycads (Vishnu-Mittre 1956, 1958; Sharma 1967, 1969, 1974, 1997; Sengupta 1988; Banerji 1993, 1995, 2000; Banerji and Jana 1998). Several researchers have also recorded spores and pollen from the Lower Triassic to the Lower Cretaceous (Rao 1943; Tiwari et al. 1984; Tripathi et al. 1990, 2013; Baksi

\section{Springer Open}

(-) The Author(s). 2021 Open Access This article is licensed under a Creative Commons Attribution 4.0 International License which permits use, sharing, adaptation, distribution and reproduction in any medium or format, as long as you give appropriate credit to the original author(s) and the source, provide a link to the Creative Commons licence, and indicate if changes were made. The images or other third party material in this article are included in the article's Creative Commons licence, unless indicated otherwise in a credit line to the material. If material is not included in the article's Creative Commons licence and your intended use is not permitted by statutory regulation or exceeds the permitted use, you will need to obtain permission directly from the copyright holder. To view a copy of this licence, visit http://creativecommons.org/licenses/by/4.0/. 


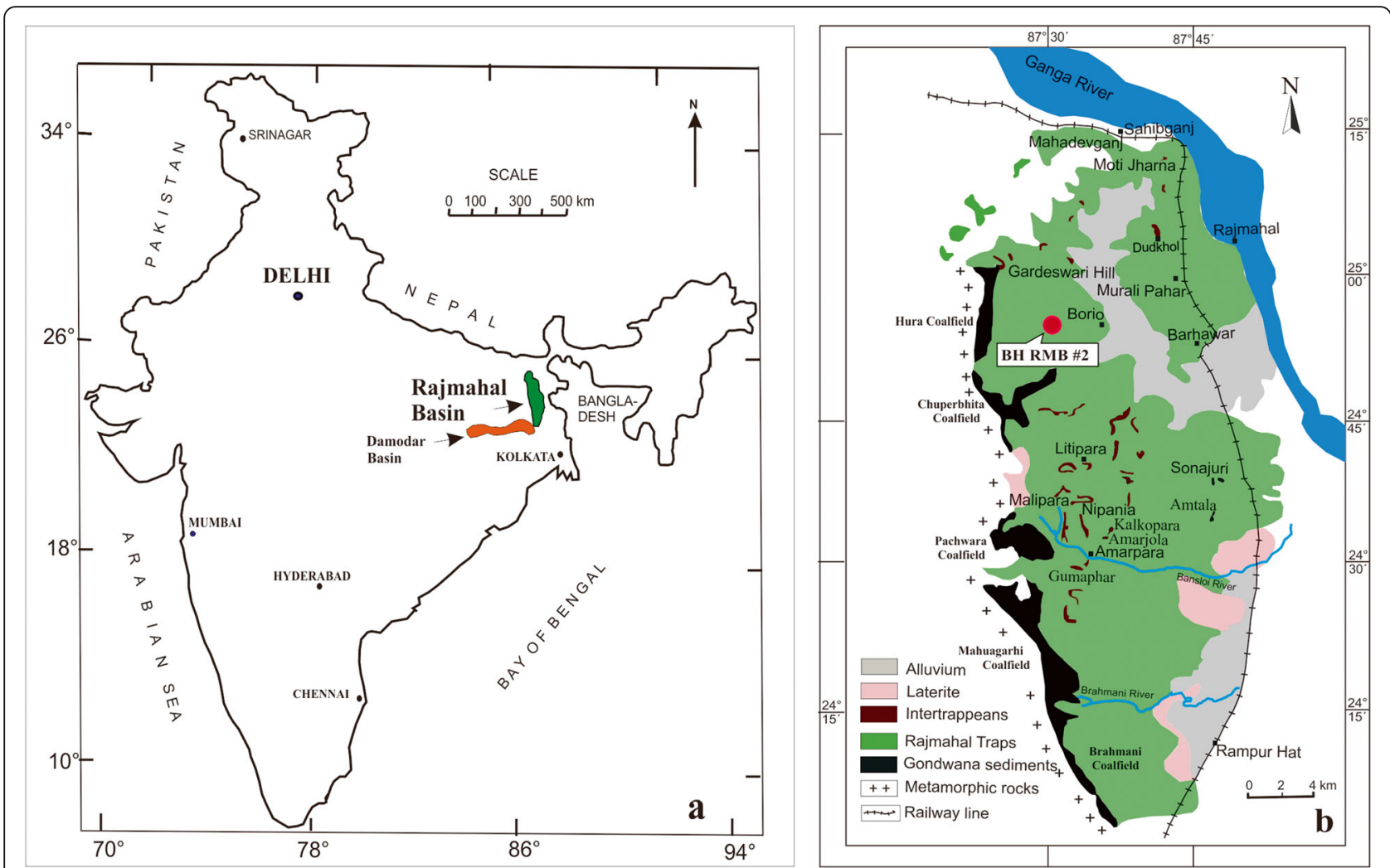

Fig. 1 a Map of India showing location of the Rajmahal Basin; $\mathbf{b}$ Geological map of the Rajmahal Basin showing location of the borehole RMB\#2 (red dot)

et al. 1992; Tiwari and Tripathi 1995; Tripathi 2001, 2002, 2004, 2008; Tripathi and Ray 2006).

The lower Gondwana sediments, represented by the Talchir and Barakar formations, can lithologically be attributed to an Early Permian age (Raja Rao 1987). They are only exposed on the western flank of Rajmahal hills as detached outcrops (marked in black shade in Fig. 1b). In some parts of the Rajmahal Basin, Talchir and Barakar formations are covered by Rajmahal traps (basic volcanics), Tertiary sediments and Gangetic alluvia, which obscure our understanding about their lateral extent. Palynological studies of the lower Gondwana sediments in the Rajmahal Basin are comparatively rare and mainly built on subsurface sediments. Maheshwari (1967) first recovered a miospore assemblage and classified its genera from the lower Gondwana rocks at Bansloi valley and Rajmahal hills through a morphological study. Later on, Srivastava and Maheshwari (1974) performed a palynological study for an outcrop in the Brahmani Coalfield and identified an assemblage comprising 27 spore-pollen genera characterized by the dominance of Faunipollenites, Gondwanapollenites, Densipollenites and Sulcatisporites (=Scheuringipollenites), indicating the Late Permian (Barren Measures Formation). Ghosh et al. (1984) recovered an assemblage from a coal seam in the
Chattgham area of the Chuperbhita Coalfield, and this assemblage comprises a dominance of striate bisaccate pollens (Faunipollenites, Striatites, Stotersporites, Lahirites) and a sub-dominance of trilete spores (Punctatisporites and Psilalacinites) followed by a very low proportion of monosaccates (mainly Densipollenites), suggesting a late Early Permian age (Barakar Formation). Banerjee and D'Rozario (1988), Banerjee and D'Rozario 1990) reported three assemblage zones for the lower Permian sediments of the Chuperbhita Coalfield: (1) the Plicatipollenites-Parasaccites Zone comprising a dominance of Ginkgocyladophytus and a sub-dominance of monosaccate pollens followed by Callumispora, Brevitriletes and an acritarch (Quadrisporites), indicating an Early Permian age (Karharbari Formation); (2) the nonstriate bisaccate Scheuringipollenites Zone exhibiting a dominance of non-striate bisaccate Scheuringipollenites along with Laevigatosporites, Brevitriletes, Lophotriletes and Marsupipollenites, belonging to the late Early Permian (Barakar Formation); and, (3) the striate bisaccate Striatopodocarpites-Striatites Zone showing a dominance of striate bisaccate pollens, belonging to the late Early Permian (upper part of the Barakar Formation). Earlier, Tripathi (2001) conducted a palynological analysis for the sedimentary succession of borehole RCH-51 
from the Chuperbhita Coalfield. This borehole penetrated through the Rajmahal Formation (Lower Cretaceous), the Dubrajpur Formation (Lower Cretaceous to Lower Triassic) and the coal-bearing Barakar Formation (Lower Permian). Based on palynological studies, five Permian palynoassemblages from the Barakar Formation in the Rajmahal Basin, i.e., Scheuringipollenites barakarensis, Faunipollenites varius, Densipollenites densus, Gondisporites raniganjensis and Densipollenites magnicorpus assemblage zone, were identified and were lithologically designated as Lower Permian. Recently, Murthy et al. (2018) reported two palynoassemblages: (1) palynoassemblage I, assigned to a Late Carboniferous age, dominated by monosaccate pollens and absence of spores and bisaccates; and (2) palynoassemblage II of an earliest Permian age, also dominated by monosaccates but with spores and bisaccates.

Fossil charcoal occurring in sediments is usually accepted as direct evidence for wildfires, and is considered as a good indicator for some environmental conditions (Scott and Jones 1994; Scott 2000; Scott and Glasspool 2006). Most of the reported Permian macroscopic charcoal is of gymnospermous origin and is reported from coal associated strata (Jasper et al. 2013, 2017; Benício et al. 2019). Petrological (pyrogenic inertinites) and geochemical (polycyclic aromatic hydrocarbons) evidences are additional reliable sources to reconstruct the occurrence of palaeo-wildfires in various palaeo-environments and time periods, often considered together with the macroscopic and microscopic features of fossil charcoal in clastic sediments (Jones and Chaloner 1991; Scott 2000; Jasper et al. 2013). Evidence for palaeo-wildfires is available in the fossil record from the Upper Silurian (Glasspool et al. 2004) up to the Quaternary (Scott 1989,
2000, 2010; MacDonald et al. 1991; Scott and Glasspool 2006; Flannigan et al. 2009; Belcher et al. 2010).

In comparison to numerous studies dealing with macroscopic charcoal from Upper Paleozoic sediments of the Northern Hemisphere, there are rather few investigations of this kind from the Southern Hemisphere, although the relevant evidence is steadily increasing (e.g., Benício et al. 2019; Scott 2000). Jasper et al. (2012) was the first to study macroscopic charcoal from Permian sediments of the Indian Gondwana, the Raniganj Coalfield in the Damodar Basin. Subsequently, Mahesh et al. $(2015,2017)$ reported Middle-Late Permian macroscopic charcoal from the South Karanpura Coalfield in the Damodar Basin and Late Permian macroscopic charcoal from the Mand-Raigarh Coalfield in the Mahanadi Basin. Additionally, Jasper et al. (2016) reported Late Permian charcoal from the Zewan Formation in the Kashmir area, Northwest Himalaya, and Jasper et al. (2017) reported Early Permian charcoal from the Dhanpuri coalmine of the Shohagpur Coalfield in the South Rewa Gondwana Basin.

Wildfire events in modern time are usually considered by governments and the public as a destructive menace; however, they are an essential part of several natural environments (Vogl 1977; Bowman et al. 2009; Flannigan et al. 2009). Since the appearance of the first embryophytic landplants in the Silurian, wildfire events occurred in different ecosystems (Glasspool et al. 2004). The frequency and intensity of wildfires are more or less directly related to climatic conditions, as fires depend on a variety of factors such as temperature, wind, moisture content, and also depend on the development of flammable biomass at temporal and spatial scales (availability of fuel) (Swetnam 1993; Scott 2000; Scott et al. 2014). During a wildfire, the incomplete combustion of plant material leads to the

Table 1 Generalized stratigraphical succession of the Rajmahal Basin (after Raja Rao 1987; Tiwari and Tripathi 1995; Tripathi 2008)

\begin{tabular}{|c|c|c|}
\hline Series & Lithostratigraphic Unit & Lithology \\
\hline Recent & Alluvium & Loose soil, silt, and clay \\
\hline \multirow[t]{2}{*}{ Upper Tertiary } & & Coarse- to medium-grained sandstone, gravel, pebble beds \\
\hline & ------1 & ormity---------- \\
\hline Lower Cretaceous & $\begin{array}{l}\text { Rajmahal Formation (traps and } \\
\text { intertrappean) }\end{array}$ & $\begin{array}{l}\text { Flows of basalt, pitchstone and intertrappean beds (sandstone, shale, } \\
\text { ash) }\end{array}$ \\
\hline \multirow[t]{2}{*}{$\begin{array}{l}\text { Lower Triassic to Lower } \\
\text { Cretaceous }\end{array}$} & Dubrajpur Formation & $\begin{array}{l}\text { Pebbly and coarse- to medium-grained sandstone, siltstone, clay, grey to } \\
\text { pink shale }\end{array}$ \\
\hline & $---1-+-$ & ormity---------- \\
\hline Upper Permian & & Coal, shale, sandstone \\
\hline \multirow[t]{3}{*}{ Lower Permian } & Barakar Formation & $\begin{array}{l}\text { Coarse- to medium-grained and pebbly sandstone, grey shale, clay and } \\
\text { coal }\end{array}$ \\
\hline & Talchir Formation & Tillite, fine- to medium-grained sandstone, olive-green shale \\
\hline & -+- & ormity--------- \\
\hline Precambrian & & Basement rocks, amphibolite, quartzite, gneiss and granite \\
\hline
\end{tabular}


formation of charcoal. In siliciclastic sediments, wildfire events can be reconstructed based on various methods including analyses of charcoal, pyrogenic inertinite maceral (i.e., fusinite, semifusinite and inertodetrinite) and polyaromatic hydrocarbon compounds. The occurrence of unsubstituted three- to seven-ring polycyclic aromatic hydrocarbons (PAHs) in the host sediments is directly related to the burning of plant biomass and thus these compounds can also be used as direct indicators for palaeo-wildfire events (Venkatesan and Dahl 1989; Killops and Massoud 1992; Finkelstein et al. 2005; Marynowski and Simoneit 2009; Bond and Scott 2010; Scott et al. 2010; Marynowski et al. 2011; Denis et al. 2012; Kubik et al. 2020).

The main objectives of this study are: (1) to date the succession of the borehole RMB\#2 palynologically, and to highlight the biostratigraphic status of the Barakar Formation of Rajmahal Basin and correlate its biostratigraphy with contemporary palynoassemblages recorded from other Indian Gondwana basins; (2) to analyze the anatomy of macroscopic fossil charcoal embedded in two sediment samples at depths of $88 \mathrm{~m}$ and $93 \mathrm{~m}$ of the core; and, (3) to provide a biomarker analysis of saturated and aromatic fractions on the two samples and to identify significant fire-related compounds as well as various other biomarkers in these samples.

\section{Geological setting}

The Rajmahal Basin is located to the northeast of the Damodar Basin in northern Peninsular India (Fig. 1a). The basin is trending in north-south direction, and the Gondwana sediments are found in the area bounded in the north by the Ganga River, in the east by Rajmahal traps, in the west by metamorphic rocks, and in the south by laterite and alluvium (Fig. 1b). A number of detached outcrops of the Gondwana sediments are exposed laterally at the western flank of the Rajmahal Basin. A NNW-SSE trending linear chain of Gondwana outcrops is known from north to south as Hura, Chuperbhita, Pachwara, Mahuagarhi, and Brahmani coalfields (Fig. 1b). The Gondwana outcrops bearing coal deposits occur along the Bansloi and Brahmani rivers at the

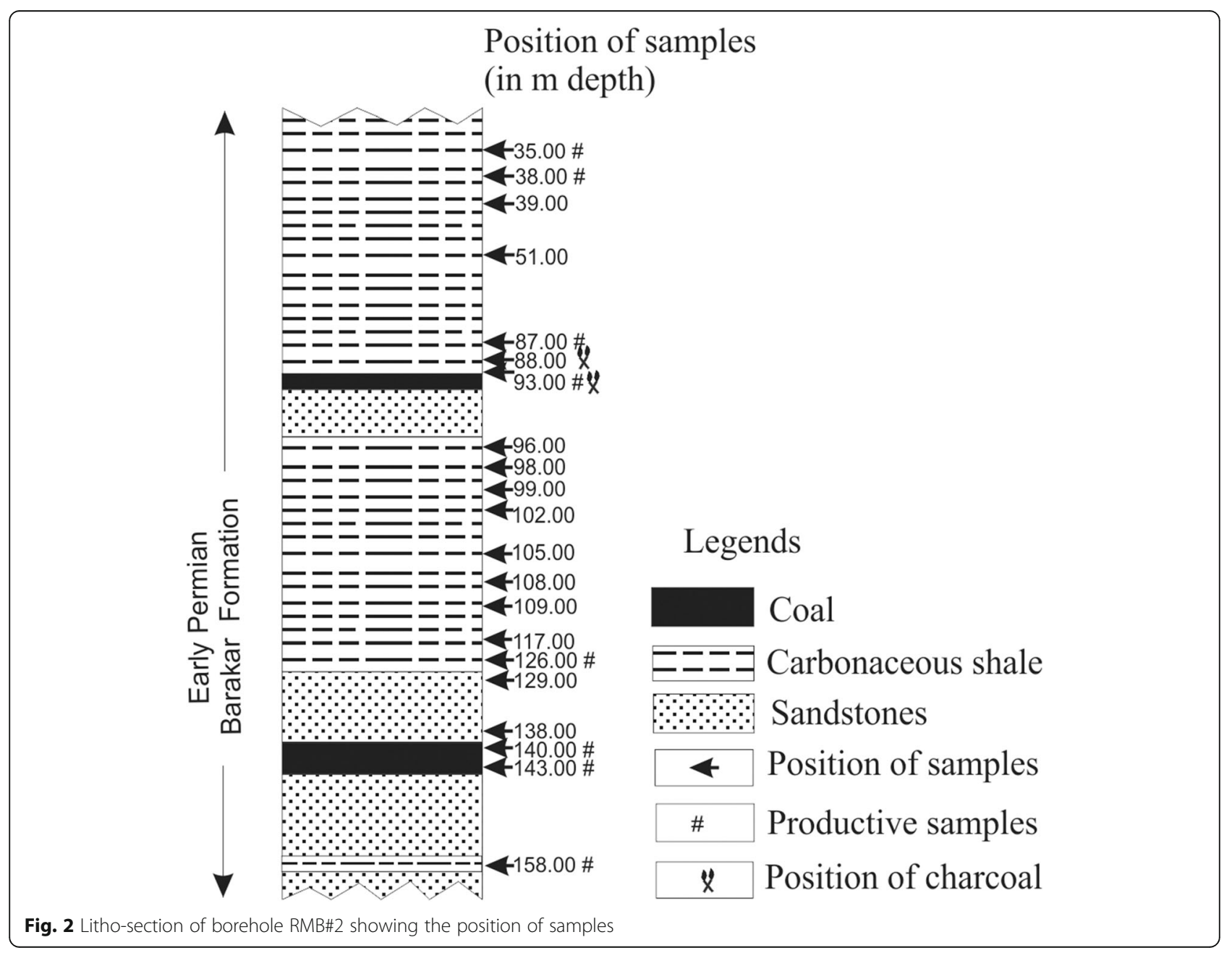


western margin of this basin. The hidden extension of individual coalfields covered by Rajmahal traps in this belt in all probability connects adjoining ones, which in some cases is supported by geophysical data.

The general stratigraphic succession of the Gondwana strata developed in the Rajmahal Basin (Raja Rao 1987) is shown in Table 1. The whole succession was divided into the Lower and Upper Gondwana Groups - the Lower Gondwana Group comprises the Early Permian Talchir Formation (Asselian-Sakmarian) and the Early Permian Barakar Formation (Artinskian-Kungurian), while the Upper Gondwana Group is characterized by the Dubrajpur and Rajmahal formations (Ball 1877). The Dubrajpur Formation overlies the Barakar Formation with an unconformity, showing that denudation was active between the two periods of deposition (Tiwari et al. 1984).

The samples analyzed in this study originate from borehole RMB \#2 (Fig. 2), which was drilled in the Dhulia Coal Block, Rajmahal Basin.

\section{Material and methods}

This study includes analyses of palynomorphs, charcoal and organic geochemistry for samples from the borehole

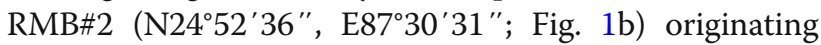
from the Dhulia Coal Block in the Rajmahal Basin, India. Twenty-one subsurface samples were collected for the palynological study and two carbonaceous shale samples (at depths of $88 \mathrm{~m}$ and $93 \mathrm{~m}$ respectively) comprising macroscopic charcoal were selected for charcoal anatomy and organic geochemistry analysis (Fig. 2). The slides containing the palynomorphs, vide Statement No.1525 with Museum slide numbers 16513-16517, were placed in the repository of the Birbal Sahni Institute of Palaeosciences (BSIP), Lucknow, India.

\subsection{Palynology}

For palynological study, $50 \mathrm{~g}$ of each sample were manually crushed and prepared by standard maceration procedures to observe clear palynomorphs. The maceration procedure involved adding hydrofluoric acid (40\% HF) for elimination of silicates and other mineral impurities from the powdered samples. The demineralised acid-free filtrate was oxidized by concentrated nitric acid $\left(\mathrm{HNO}_{3}\right)$ to eliminate the humic units. The filtrate of organic matter was sieved by using $400 \mu \mathrm{m}$ sieves and mounted on the glass slides using polyvinyl and Canada balsam. For each sample, five separate glass slides were prepared and studied using transmitted light microscope (Olympus BX61) attached with a DP-25 camera.

\subsection{Charcoal}

Macroscopic charcoal fragments occurred in two carbonaceous shale samples at depths of $88 \mathrm{~m}$ and $93 \mathrm{~m}$ of the borehole RMB\#2 (Fig. 2). The studied charcoal fragments were separated mechanically in the laboratory through the help of a dissecting knife and needles from the core under an illuminated magnifier with a flexible arm. Then the charcoal fragments were mounted on stubs with an both-sided adhesive carbon tape, and coated with gold by using a gold-palladium coater (JEC 3000PC). The gold-coated pieces were studied and photographed under an JEOL 7610F Field Emission Scanning Electron Microscope (FESEM).

\subsection{Organic geochemistry}

The soluble organic matter was isolated from the ovendried powdered samples by using an ultrasonic stirrer with the solution prepared in a specific ratio of dichloromethane and methanol (9:1) for about $30 \mathrm{~min}$. Then, asphaltenes were separated through the precipitation

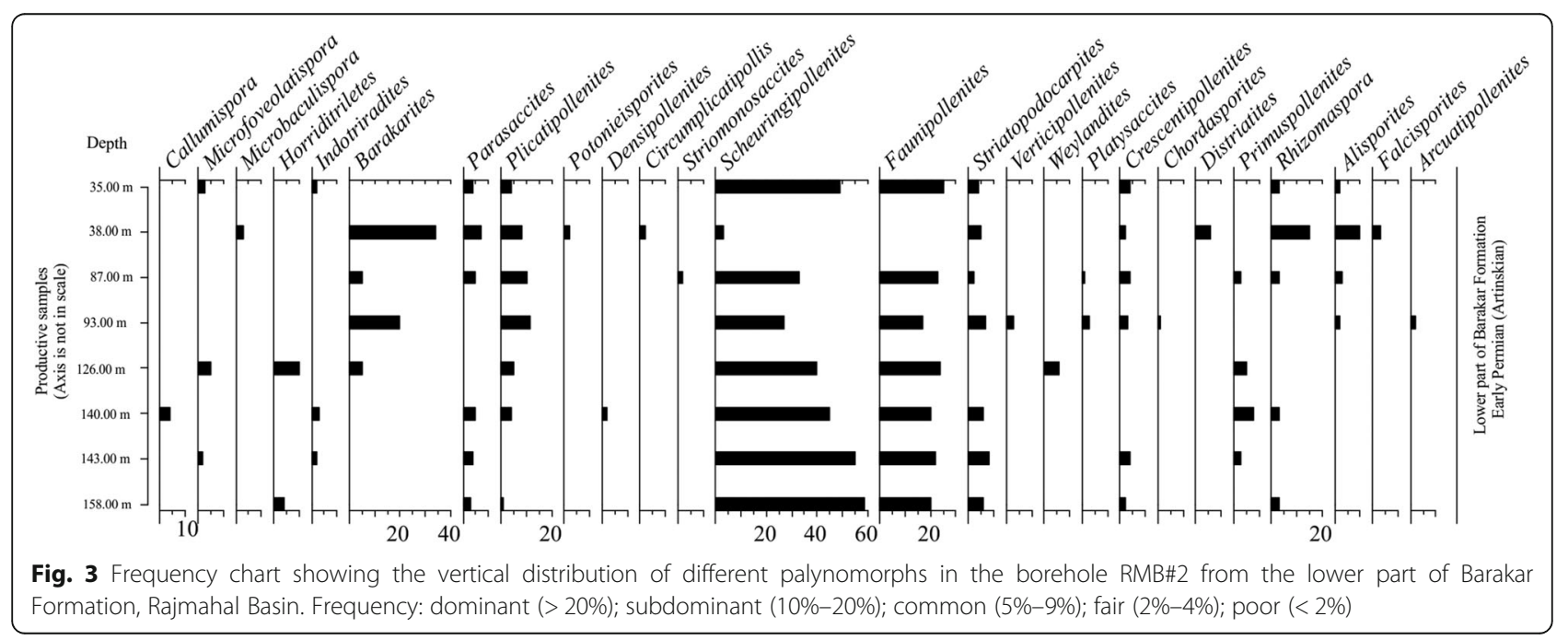


process with the help of an excess of $n$-hexane $(40 \mathrm{ml})$. The fractionation was carried out by passing the extract in a chromatographic column comprising silica gel (activated) with $n$-hexane for saturates and dichloromethane-hexane (ratio of 1:4) solution for aromatic determination present in the sample. The gas chromatograph (GC, which an attachment of a fused silica capillary column (HP-5MS) with a length and diameter of $30 \mathrm{~mm} \times 0.25 \mathrm{~mm}$ and film thickness of $0.25 \mu \mathrm{m}$ ) system of Agilent 7890B interfaced to an Agilent 5977A mass spectrometer (MS) was used for analysis. Helium (He) was used to carry the sample gas in the capillary column (carrier gas) maintaining a flow rate of $1 \mathrm{ml} / \mathrm{min}$. The oven temperature of the GC was kept at $40^{\circ} \mathrm{C}$ for the initial $5 \mathrm{~min}$, and subsequently increased to $310^{\circ} \mathrm{C}$ at a rate of $4{ }^{\circ} \mathrm{C} / \mathrm{min}$. To avoid analytical errors, the full scan $(m / z 50-550) 70 \mathrm{eV}$ mass spectra were assimilated with a source temperature of $300{ }^{\circ} \mathrm{C}$. The Chemstation software was used for data processing. Different peaks obtained in spectra were identified against the retention time of various gases in GC. Moreover, mass spectral data were compared with the mass spectral libraries and/or the published mass spectra for validation of the results.

\section{Results}

\subsection{Palynological analysis}

Eight of the 21 samples, respectively at the depths of 35 $\mathrm{m}, 38 \mathrm{~m}, 87 \mathrm{~m}, 93 \mathrm{~m}, 126 \mathrm{~m}, 140 \mathrm{~m}, 143 \mathrm{~m}$ and $158 \mathrm{~m}$ of the borehole RMB\#2 (Fig. 2), yielded abundant palynomorphs together with dark debris (organic matter). Additional ten samples (at depths of $88 \mathrm{~m}, 96 \mathrm{~m}, 98 \mathrm{~m}, 99 \mathrm{~m}$, $102 \mathrm{~m}, 105 \mathrm{~m}, 108 \mathrm{~m}, 109 \mathrm{~m}, 117 \mathrm{~m}$, and $129 \mathrm{~m}$, respectively) yielded only lath- to uneven-shaped dark debris. The remaining three samples (at depths of $39 \mathrm{~m}, 51 \mathrm{~m}$, and $138 \mathrm{~m}$, respectively) were barren of palynomorphs and/or dark debris. Quantitative and qualitative palynological analyses reveal that there is just one palynoassemblage in the samples from the borehole RMB\#2. The recovered palynoassemblage is moderately diverse and comprises spores and pollen. The vertical distribution of the different palynomorphs is shown in Fig. 3.

The list of palynomorph taxa recorded in the borehole RMB\#2 and their botanical affinities are presented in Table 2 (Balme 1995; Lindström and McLoughlin 2007; di Pasquo and Grader 2012; Mishra et al. 2017). Preservation of spore-pollens is variable within the samples. The specimens are yellowish to dark brown in colour, distorted and fairly well preserved. Recovery of spore-pollens is very good and can be low to moderate. Stratigraphically significant palynotaxa are presented in Figs. 4 and 5.

The palynoassemblage is categorized by the ascendency of the non-striate bisaccate pollen Scheuringipollenites spp. $(33 \%-61 \%)$ and sub-dominance of the striate bisaccate pollen
Table 2 List of palynomorph taxa recorded in the borehole RMB \#2 (based on Balme 1995; Lindström and McLoughlin 2007; di Pasquo and Grader 2012; Mishra et al. 2017)

\begin{tabular}{|c|c|}
\hline Palynotaxa identified in this study & Botanical affinity \\
\hline Callumispora sp. & Filicales \\
\hline Microfoveolatispora foveolata & Filicales \\
\hline Microbaculispora indica & Filicales \\
\hline Horriditriletes sp. & Filicales \\
\hline Indotriradites sparsus & Lycopsidales \\
\hline Indotriradites sp. & Lycopsidales \\
\hline Barakarites indicus & Cordaitales \\
\hline Barakarites sp. & Cordaitales \\
\hline Circumplicatipollis sp. & Cordaitales \\
\hline Densipollenites indicus & Cordaitales \\
\hline Parasaccites korbaensis & Cordaitales \\
\hline Parasaccites densicorpus & Cordaitales \\
\hline Parasaccites ovatus & Cordaitales \\
\hline Parasaccites sp. & Cordaitales \\
\hline Plicatipollenites indicus & Cordaitales \\
\hline Plicatipollenites gondwanensis & Cordaitales \\
\hline Potonieisporites novicus & Cordaitales \\
\hline Striomonosaccites ovatus & Cordaitales \\
\hline Striomonosaccites sp. & Cordaitales \\
\hline Faunipollenites varius & Glossopteridales \\
\hline Faunipollenites singrauliensis & Glossopteridales \\
\hline Faunipollenites sp. & Glossopteridales \\
\hline Striatopodocarpites magnificus & Glossopteridales \\
\hline Scheuringipollenites barakarensis & Glossopteridales \\
\hline Scheuringipollenites maximus & Glossopteridales \\
\hline Scheuringipollenites tentulus & Glossopteridales \\
\hline Verticipollenites gibbosus & Glossopteridales \\
\hline Weylandites sp. & Glossopteridales \\
\hline Platysaccus sp. & Glossopteridales \\
\hline Crescentipollenites fuscus & Coniferales \\
\hline Chordasporites sp. & Coniferales \\
\hline Distratites bilateris & Coniferales \\
\hline Primuspollenites levis & Coniferales \\
\hline Rhizomaspora indica & Coniferales \\
\hline Alisporites indicus & Coniferales \\
\hline Alisporites sp. & Coniferales \\
\hline Falcisporites zapfei & Coniferales \\
\hline Arcuatipollenites sp. & Coniferales \\
\hline
\end{tabular}

Faunipollenites (=Protohaploxypinus) $\quad$ spp. (10\%-25\%). Meanwhile, the palynotaxa recovered in this palynoassemblage are striate bisaccates represented by Rhizomaspora (015\%), Striatopodocarpites (0-8\%), Primuspollenites (0-8\%), 

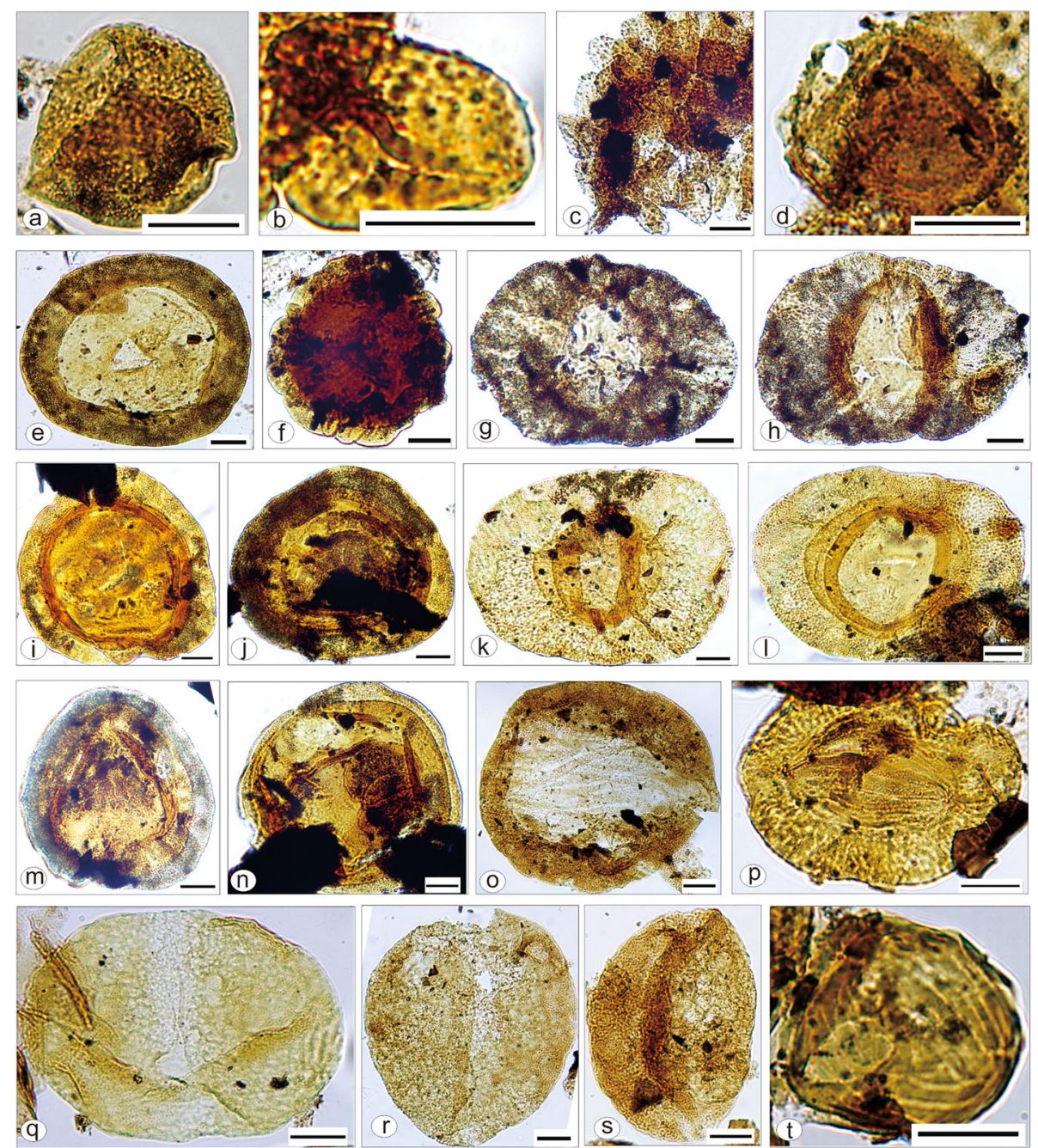

Fig. 4 Light microscopic photographs of representative palynomorphs from the borehole RMB\#2 in the lower part of the Barakar Formation, Rajmahal Basin. a Microfoveolatispora foveolata Tiwari 1965 (BSIP Slide No. 16513, N42); b Microbaculispora indica Tiwari 1965 (BSIP Slide No. 16514 G32); c Horriditriletes sp. (BSIP Slide No. 16516, R46/4); d Indotriradites sp. (BSIP Slide No. 16514, H54); e Parasaccites korbaensis Bharadwaj \& Tiwari 1964 (BSIP Slide No. 16517, F56); f Parasaccites densicorpus Lele 1975 (BSIP Slide No. 16515, X50); g Parasaccites ovatus Kar 1968 (BSIP Slide No. 16514, U35); h Parasaccites sp. (BSIP Slide No. 16513, S45); i Plicatipollenites indicus Lele 1963 (BSIP Slide No. 16513, P33); j Circumplicatipollis sp. (BSIP Slide No. 16513, J48/3); k Plicatipollenites gondwanensis (Balme \& Hennely) Lele 1964 (BSIP Slide No. 16514, U38/2); I) Potonieisporites novices Bharadwaj 1954 (BSIP Slide No. 16513, V65); m Barakarites sp. (BSIP Slide No. 16515, R34/4); n Densipollenites indicus Bharadwaj 1962 (BSIP Slide No. 16513, U42/2); o Striomonosaccites ovatus Bharadwaj 1962 (BSIP Slide No. 16517, T61/3); p Striomonosaccites sp. (BSIP Slide No. 16513, Q45/2); q Scheuringipollenites barakarensis Tiwari 1973 (BSIP Slide No. 16517, T36); r Scheuringipollenites maximus Tiwari 1973 (BSIP Slide No. 16517, M30); s) Scheuringipollenites tentulus Tiwari 1973 (BSIP Slide No. 16517; O60/3); t Weylandites sp. (BSIP Slide No. 16516, Q59). Black bar scale $=20 \mu \mathrm{m}$

Distriatites (0-6\%), Crescentipollenites (0-4\%) and Verticpollenites (0-3\%), and other non-striate bisaccates represented by Alisporites (0-10\%), Falcisporites (0-3\%) and Platysaccus (0-1\%); monosaccates represented by Barakarites (0-41\%), Plicatipollenites (0-16\%), Parasaccites (0-7\%), Densipollenites $(0-2 \%)$ and Striomonosaccites (0-2\%) occurring in variable frequency; Triletes represented by Horriditriletes ( 0 $10 \%)$, Weylandites (0-6\%), Microfoveolatispora (0-5\%), Callumispora (0-4\%), and Indotriradites (0-3\%) have low counts; and, taeniate bisaccates represented by Arcuatipollenites $(0-2 \%)$ and Chordasporites $(0-1 \%)$ are rare.

\subsection{Charcoal analysis}

\subsubsection{Identification of charcoal}

Two samples contain many well-preserved charcoal fragments embedded in carbonaceous shale (Figs. 2, 6). The size (length $\times$ width $\times$ thickness) of the charcoal fragments ranges from $20 \times 10 \times 2 \mathrm{~mm}$ to $25 \times 15 \times 3 \mathrm{~mm}$ (Fig. 6). 

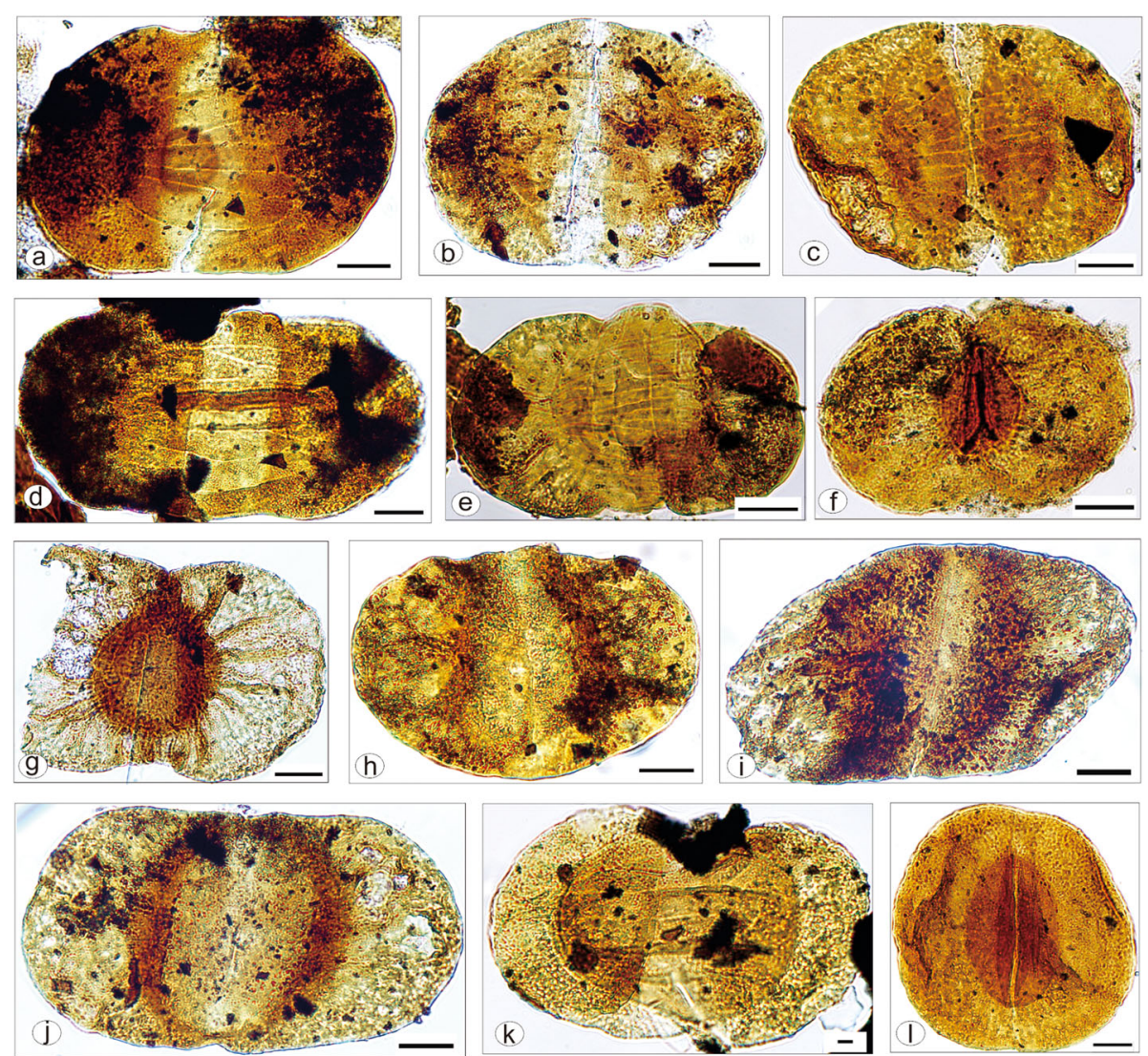

Fig. 5 Light microscopic photographs of representative palynomorphs from the borehole RMB\#2 in the lower part of the Barakar Formation, Rajmahal Basin. a Faunipollenites varius Bharadwaj 1962 (BSIP Slide No. 16514, J62/4); b Faunipollenites singrauliensis Sinha 1972 (BSIP Slide No. 16514, F39-G39); c Crescentipollenites fuscus (Bharadwaj) Bharadwaj, Tiwari and Kar (1974) (BSIP Slide No. 16514, O43/2); d Chordasporites sp. (BSIP Slide No. 16513, O52/1-3); e Distratites bilateris Bharadwaj 1962 (BSIP Slide No. 16513, U42/2); f Primuspollenites levis Tiwari 1964 (BSIP Slide No. 16516, X46); g Rhizomaspora indica Tiwari 1964 (BSIP Slide No. 16514, L55-M55); h Alisporites indicus Bharadwaj \& Srivastava 1969 (BSIP Slide No. 16513, V63/3); i Falcisporites zapfei Leschik emend. Klaus 1963 (BSIP Slide No. 16514, U28/1); j Alisporites sp. (BSIP Slide No. 16514, U49/1-3); k) Striatopodocarpites magnificus Bharadwaj and Salujha 1964 (BSIP Slide No. 16515, S54); I Primuspollenites sp. (BSIP Slide No. 16517, O60). Black bar scale $=20 \mu \mathrm{m}$

Edges of the individual fragments are not abraded in most of the specimens. Based on the large sizes, sharp edges and excellent anatomical preservation of the charcoal fragments (Figs. 7, 8, 9), it can be hypothesized that these specimens did not experience considerable transport before deposition.

The identification of fossil charcoal is based on the criteria proposed by Jones and Chaloner (1991) and Scott (2000, 2010): the specimen has black colour with silky luster, homogenized cell wall and well-preserved internal anatomical structure, although shattered due to sediment compaction (Figs. 7, 8, 9). All samples in this study exhibit homogenized cell walls (Figs. 7d, f, 8b, c, 9c, f) and excellent preservation of the anatomical structure of fossil charcoal. In cross-section, the typical "Bogenstrukturen" are visible (Figs. 7f, 9f), which are indicative for in-situ shattered charcoal in coals and fine-grained siliciclastics (Sander and Gee 1990; Scott 2000; Uhl et al. 2004, 2008, 2010; Kubik et al. 2015).

\subsubsection{Anatomical characteristics of charcoal}

The studied charred woody tissues are not preserved three-dimensionally all over the charcoal specimens (Fig. 6). Most of the macroscopic charcoal fragments preserve anatomical structures in small areas, due to compaction. The homogenization of cell walls is clearly visible in tracheids of almost all samples (Figs. 7d, f, 8b, c, 9c, f). Tracheid walls exhibit uniseriate (Fig. 8d) and biseriate, alternating bordered pits (Figs. 7c, 9c, d). Most of the pits are oval with a diameter of $4-6 \mu \mathrm{m}$, some are smaller with a diameter of $2-2.5 \mu \mathrm{m}$; circular pits are also observed (Fig. 9c, d). Rays of one-cell-height with a diameter range of $28-70 \mu \mathrm{m}$ (Figs. $7 \mathrm{~b}, \mathrm{~d}, 8 \mathrm{~b}, \mathrm{c}, 9 \mathrm{~b}$ ) and uniseriate pits are visible in tangential view. Fungal 

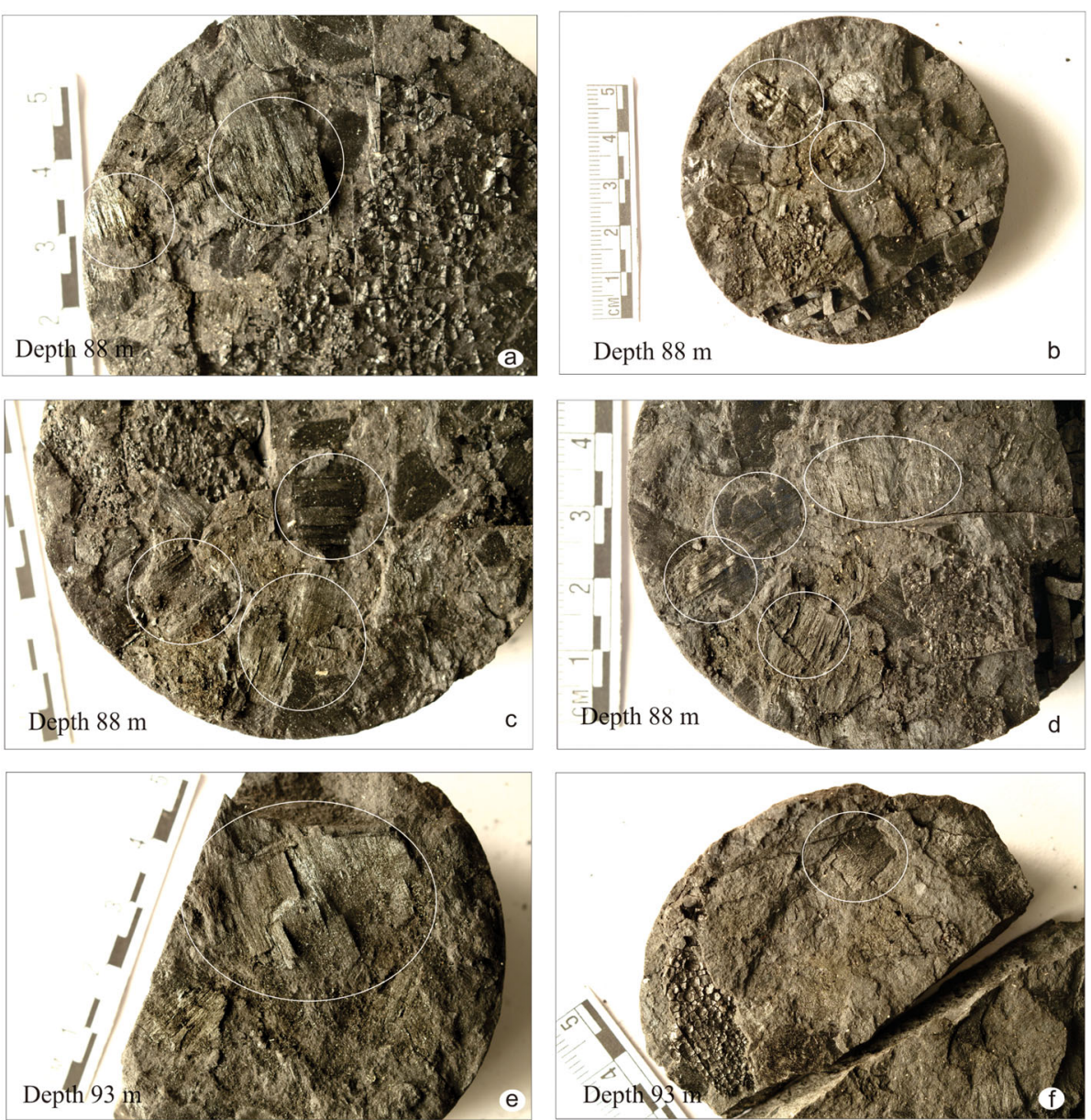

Fig. 6 Photographs showing macroscopic fossil charcoal fragments (marked by circles) embedded in the carbonaceous shale from borehole RMB\#2 at depths of $88 \mathrm{~m}(\mathbf{a}-\mathbf{d})$ and $93 \mathrm{~m}(\mathbf{e}-\mathbf{f})$. $\mathbf{a}-\mathbf{b}$ Charcoal specimens with sharp edges, indicative of very short transport; c Relatively large charcoal fragments. The upper specimen exhibits slightly abraded edges, indicative of some transport before deposition; $\mathbf{d}$ Charcoal fragments with partly slightly abraded edges, indicative of some transport before deposition; e Large charcoal specimen, approximately $25 \mathrm{~mm}$ long, with sharp unabraded edges, indicative of short transport; $\mathbf{f}$ Smaller, almost quadratic charcoal fragment with sharp edges, indicative of very short transport

infestation in the charred wood is documented by fungal hyphae on the walls (Fig. 8c, e). "Shot-like holes" (Schweingruber 1990) which are round and considerably smaller than pits can be observed in cell walls of tracheids (Fig. 8c, d). Such so-called "shot-like holes" are produced by selective decay of components of the cell wall in living wood by fungi or tunneling bacteria (Schweingruber 1990; Daniel 2003; Schweingruber et al. 2006; Schwarze 2007; Singh et al. 2016). Comparable "shot-like holes" are also known from other occurrences of fossil charcoal and interpreted as evidence of precharring decay by microorganisms (El Atfy et al. 2019; Uhl et al. 2020).

\subsubsection{Organic chemistry of charcoal}

A biomarker analysis of the saturated fraction and aromatic fraction was performed on the two samples. The major compounds identified in these samples are listed in Tables 3 and 4 . The different biomarker parameters are given in Table 5 .

4.2.3.1 n-alkanes and isoprenoids: The $n$-alkanes and isoprenoids were recognized using the selected mass chromatogram $m / z 57$, and their distribution in the samples are provided in Fig. 10. The $n$-alkane hydrocarbon fractions are constituted by the homologous series extending from $\mathrm{C}_{14}$ to $\mathrm{C}_{31}$. A significant bimodal distribution pattern of $n$-alkane is apparent in both the samples with the ascendency of $n-C_{17}, n-C_{25}$ hydrocarbons. The short-chain $n-C_{15}$ to $n-C_{20}$ alkanes seem to have no considerable odd-to-even pattern and are dominated by $n$ $\mathrm{C}_{17}$ alkane in both the samples. The carbon preference index (CPI) suggested by Bray and Evans (1961) estimated for the 88-m-depth sample is 3.35 and for the 93- 

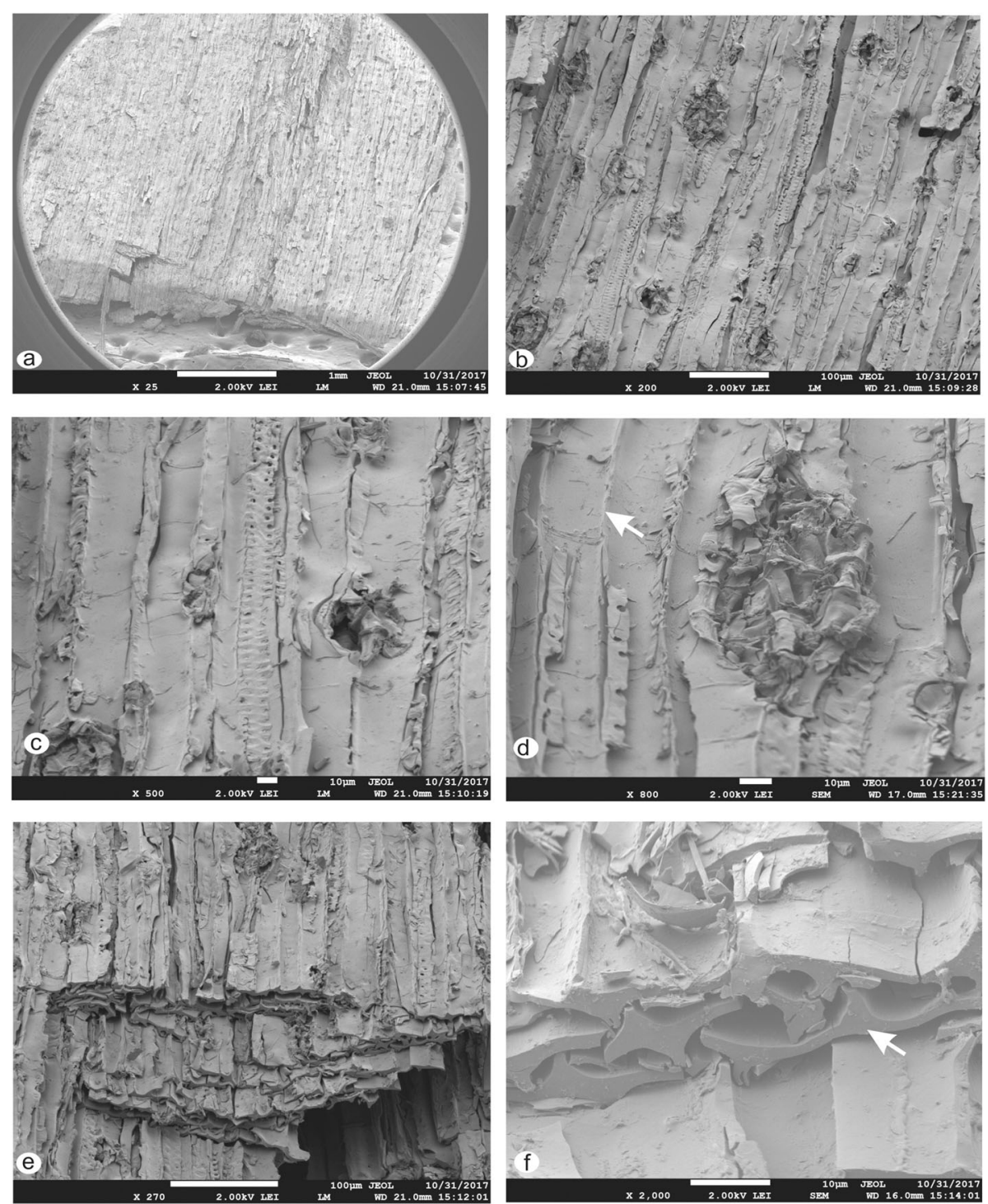

Fig. 7 Field emission scanning electron microscopic photographs of fossil charcoal fragments from $88 \mathrm{~m}$ depth of borehole RMB\#2 in the Rajmahal Basin. a Overview of the charcoal fragment in tangential view; b Tracheids in tangential view showing rays which are one cell high; $\mathbf{c}$ Detail of tracheids showing biseriate pits and rays; $\mathbf{d}$ Detail of tracheids showing homogenized cell wall (arrow) and rays; e Shattered tracheids in cross section; $\mathbf{f}$ Shattered tracheids in cross section showing homogenized cell walls (arrow) and so-called "Bogenstrukturen"

m-depth sample is 2.56 . However, in the long-chain alkanes, significant odd-to-even preference is noticeable with the dominance of $n-C_{25}$ to $n-C_{27}$. The acyclic isoprenoid hydrocarbons are recognized with an abundance of pristane $(\mathrm{Pr})$ over phytane $(\mathrm{Ph})$, in which the ratio of $\mathrm{Pr} / \mathrm{Ph}$ varies from 1.38 to 1.73 .

4.2.3.2 Terpenoids: The diterpenoids observed in the studied samples are 18-Norpimarane, Sandaracopimaradiene (?), 16 $\alpha(\mathrm{H})$-Phyllocladane, Retene, 18,19-Bisnorsimonellite, Dehydroabietane, Simonellite, and some unidentified compounds (Table 3; Fig. 11). These samples are also characterized by the high relative abundance of pentacyclic hopanoid triterpenoids. The hopane distribution is dominated with $17 \beta(\mathrm{H})-22,29,30$ Trisnorhopane and 30-Norneohop-13(18)-ene (Table 4; Fig. 12). Similarly, other important diterpenoid compounds identified are 30-Norhopane, $17 \beta(\mathrm{H}), 21 \alpha(\mathrm{H})-30$ Norhopane, $\alpha \beta$-Hopane, and $\beta \beta$-Hopane (Table 4).

4.2.3.3 Aromatic compounds: The structure of polyaromatic hydrocarbon (PAH) compounds with three to six rings are identified in the samples (Table 5; Fig. 13). These compounds include unsubstituted, oxygenated, methylated and phenyl derivatives of $\mathrm{PAH}$. 

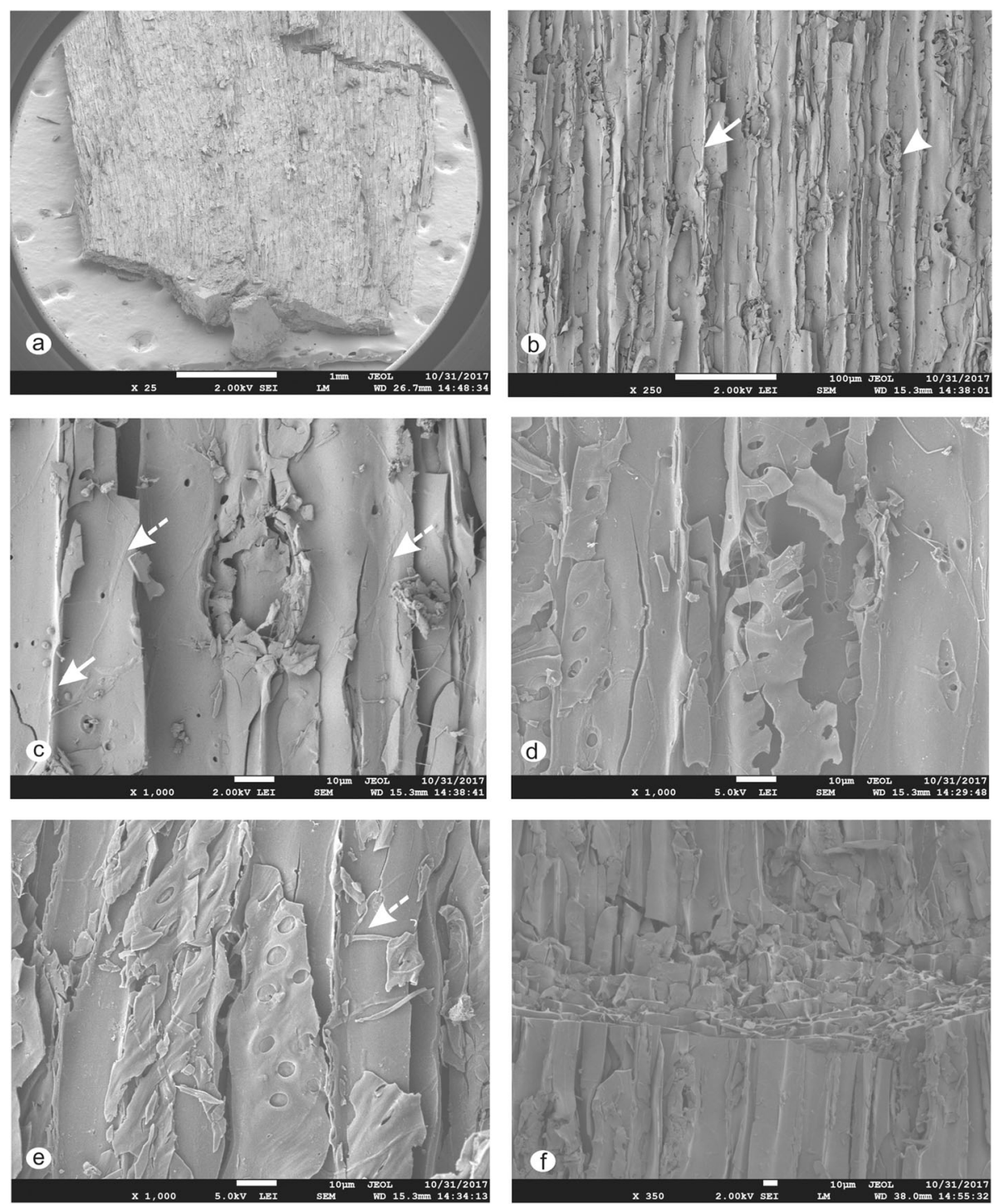

Fig. 8 Field emission scanning electron microscopic photographs of fossil charcoal fragments from $88 \mathrm{~m}$ depth of borehole RMB\#2 in the Rajmahal Basin. a Overview of the charcoal fragment in tangential view; b Tangential view showing rays (arrowhead) and homogenized cell walls (arrow); c Tracheids showing rays of one-cell-height, homogenized cell wall (arrow), remains of charred fungal hyphae (arrow with dotted line), and shot-like holes; $\mathbf{d}$ Tracheids showing uniseriate pits with diagonally oval apertures; e Tracheids showing circular pits and remains of charred fungal hyphae (arrow); $\mathbf{f}$ Shattered tracheids in oblique view

\section{Discussion}

The palynoassemblage is categorized by the dominance of Scheuringipollenites and the sub-dominance of Faunipollenites along with index species viz. Scheuringipollenites barakarensis, Scheuringipollenites maximus, Faunipollenites varius, Rhizomaspora indica, Primuspollenites levis, Verticipollenites gibbosus, Densipollenites indicus, Barakarites indicus, Indotriradites sparsus, Weylandites sp. and Horriditriletes sp. Thus, this palynoassemblage is well analogous with the Scheuringipollenites barakarensis Zone of the lower part of the Barakar Formation in the Damodar Valley Basin (Tiwari and
Tripathi 1992), and can be dated as late Early Permian (Artinskian) in age.

The statistical analysis of the sediment reveals that pollen grains predominate over spores. The qualitative analysis of palynotaxa shows an overall dominance of elements attributable to Glossopteridales in this palynoassemblage, represented by species of Faunipollenites-Scheuringipollenites, Striatopodocarpites, Verticipollenites, and Weylandites. The remaining palynotaxa of the palynoassemblage belong to (1) Cordaitales, represented by four species of Parasaccites, two species of Barakarites, two species of Plicatipollenites and Striomonosaccites, as well as one species of Potonieisporites, 

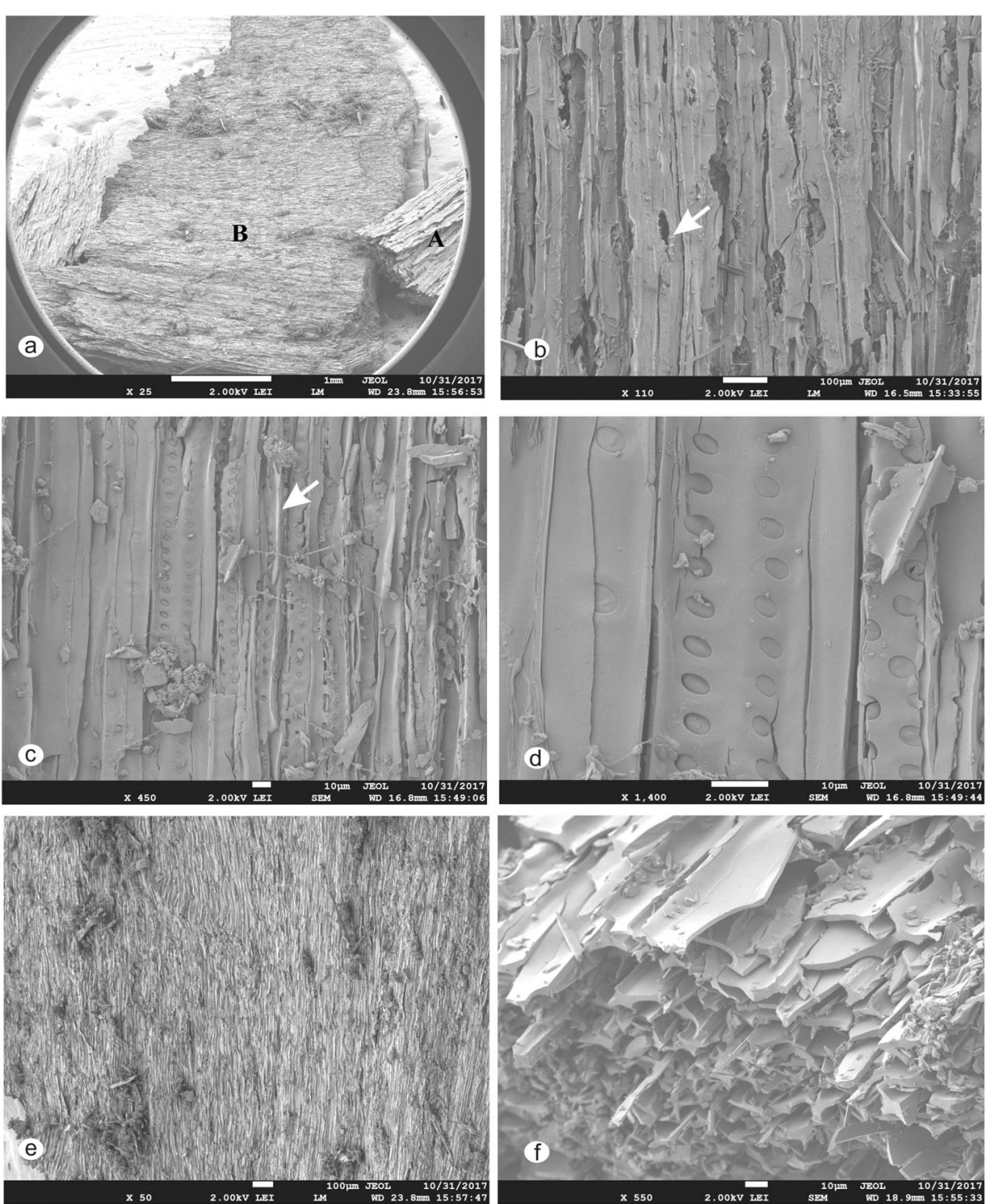

Fig. 9 Field emission scanning electron microscopic photographs of fossil charcoal fragments from $93 \mathrm{~m}$ depth of borehole RMB\#2 in the Rajmahal Basin. a Overview of two charcoal fragments (A and B); $\mathbf{b}$ Shattered tracheids in tangential view showing rays of varying heights (arrow); c Tracheids showing biseriate circular to oval pits, and homogenized cell wall (arrow); d Magnified view showing details of biseriate pits; e Details of specimen with heavily shattered tracheids due to compaction; $\mathbf{f}$ Anatomical details of heavily shattered tracheids due to compaction, showing homogenized cell wall and so-called "Bogenstrukturen"

Circumplicatipollis and Densipollenites each; (2) Coniferales, represented by two species of Alisporites, one species each of Crescentipollenites, Chordasporites, Distriatites, Primuspollenites, Rhizomaspora, Falcisporites and Arcuatipollenites; and, a small number of trilete spores including (3) Filicales represented by one species each of Callumispora, Microfoveolatispora, Microbaculispora and Horriditriletes, and (4) Lycopsidales represented by two species of Indotriradites.

The Early Permian palynoassemblages have been documented in some Gondwana basins of India such as the Rajmahal, Damodar, Son-Mahanadi, Wardha-Godavari Valley and Satpura Basin. The intrabasinal relationship and the common stratigraphically significant species of the Rajmahal Basin demonstrate that the palynoassemblage in this study is comparable to the assemblage- 1 recorded in the Chuperbita Coalfield of the Rajmahal Basin by Tripathi (2001), with palynotaxa including the dominance of Scheuringipollenites-Faunipollenites and others such as Primuspollenites, Crescentipollenites, Brevitriletes, Indotriradites, Rhizomaspora indica and Densipollenites indicus.

Regional correlation between the Rajmahal Basin and other Gondwana basins of India demonstrates that the palynoassemblage in this study compares well with the palynoassemblage-II in the borehole RT-4 from the Raniganj Coalfield in the Damodar Basin (Murthy et al. 2010) 
Table 3 Diterpenoid compounds identified in the two studied charcoal-bearing samples from 88-m- and 93-m-depth of borehole RMB\#2 in the Rajmahal Basin

\begin{tabular}{|c|c|c|c|}
\hline Peak number & Compound & Base peak & Molecular ion \\
\hline \multicolumn{4}{|c|}{ Saturated compounds } \\
\hline 1 & Unidentified Pimarane-type compound & 123 & 262 \\
\hline 2 & 18-Norpimarane & 233 & 262 \\
\hline 3 & Sandaracopimaradiene? & 257 & 272 \\
\hline 4 & 16a(H)-Phyllocladane & 123 & 274 \\
\hline \multicolumn{4}{|c|}{ Aromatic compounds } \\
\hline 1 & 18,19-Bisnorsimonellite & 209 & 224 \\
\hline 2 & Retene & 219 & 234 \\
\hline 3 & 18-/19-Norabieta-4 (19),8,11,13-tetraene? & 239 & 254 \\
\hline 4 & Dehydroabietane & 255 & 270 \\
\hline 5 & Simonellite & 237 & 252 \\
\hline 6 & C1-Simonellite? & 251 & 266 \\
\hline
\end{tabular}

and the palynoassemblage-III in the borehole MBKW-3 from the Mand-Raigarh Coalfield in Chhattisgarh in the Mahanadi Gondwana Basin (Murthy et al. 2014). The palynomorphs present in these boreholes exhibit a dominance of Scheuringipollenites-Faunipollenites along with Rhizomaspora indica, Crescntipollenites fuscus, Microfoveolatispora fovelata, Weylandites, Striamonosaccites ovatus, Barakarites indicus, and Horriditriletes sp.

The palynoassemblage of this study can be well correlated with the Barakar Formation palynoflora, which is dominated by the non-striate bisaccate pollen Scheuringipollenites followed by striate bisaccate pollen, mainly Faunipollenites, recognized in several areas of the Godavari Basin, such as the Palynoassemblage-III in Mamakannu area (Jha and Aggarwal 2010), Palynoassemblage-D in Gundala area (Jha and Aggarwal 2011), Palynoassemblage-I in Kachinapalli area (Jha and Aggarwal 2015), and Palynozone-3 in Mailaram area (Jha and Aggarwal 2012). It also correlates well with the Barakar Formation palynoflora observed in other coalfields viz., Johilla Coalfield (Zone-3: Anand-Prakash and Srivastava 1984), Umaria Coalfield (Zone-3: Srivastava and Anand-Prakash 1984), Pathakhera Coalfield (Assemblage-B: Sarate

Table 4 Pentacyclic triterpenoid compounds identified in the two studied charcoal-bearing samples from 88-m- and 93-m-depth of borehole RMB\#2 in the Rajmahal Basin. The peak assignment (peak number) is according to Fig. 12 below

\begin{tabular}{|c|c|c|c|}
\hline Peak number & Compound & Base peak & Molecular ion \\
\hline 1 & 30-Norhopane & 191 & 398 \\
\hline 2 & 17a(H)-22,29,30-Trisnorhopane (Tm) & 191 & 370 \\
\hline 3 & $17 \beta(H)-22,29,30-$ Trisnorhopane & 149 & 370 \\
\hline 4 & 30-Norneohop-13(18)-ene & 191 & 396 \\
\hline 5 & 30-Norhopane & 191 & 398 \\
\hline 6 & $17 \beta(H), 21 a(H)-30-$ Norhopane & 177 & 398 \\
\hline 7 & aß-Hopane & 191 & 412 \\
\hline 8 & Neohop-13(18)-ene isomer & 191 & 410 \\
\hline 9 & $17 \beta(H), 21 \beta(H)-30-$ Norhopane & 177 & 398 \\
\hline 10 & aß-Hopane & 191 & 412 \\
\hline 11 & $17 a(H), 21 \beta(H)-H o m o h o p a n e(22 S)$ & 191 & 426 \\
\hline 12 & $17 a(H), 21 \beta(H)$-Homohopane (22 R) & 191 & 424 \\
\hline 13 & $\beta \beta$-Hopane & 191 & 412 \\
\hline 14 & $17 \beta(H), 21 \beta(H)$-Homohopane & 205 & 426 \\
\hline 15 & $17 \beta(H), 21 \beta(H)-30,31-$ Bishomohopane & 219 & 440 \\
\hline
\end{tabular}


Table 5 Aromatic compounds identified in the two studied charcoal-bearing samples from 88-m- and 93-m-depth of borehole RMB\#2 in the Rajmahal Basin. The peak assignment is according to Fig. 13 below

\begin{tabular}{|c|c|c|}
\hline Peak number & Compound & Molecular ion \\
\hline 1 & Anthracene & 178 \\
\hline 2 & Dimethyldibenzofuran & 196 \\
\hline 3 & 3-Methylphenanthrene & 192 \\
\hline 4 & 2-Methylphenanthrene & 192 \\
\hline 5 & 9-Methylphenanthrene/4-Methylphenanthrene & 192 \\
\hline 6 & 1-Methylphenanthrene & 192 \\
\hline 7 & Fluoranthene & 202 \\
\hline 8 & Ethyl methylanthracene & 220 \\
\hline 9 & Pyrene & 202 \\
\hline 10 & 4-Phenyldibenzofuran? & 244 \\
\hline 11 & Benzo[a]anthracene? & 228 \\
\hline 12 & Methylbenzo[a]anthracene & 242 \\
\hline 13 & Methylbenzo[c]phenanthrene & 242 \\
\hline 14 & 4-Phenylphenanthrene & 254 \\
\hline 15 & Benzofluoranthenes & 252 \\
\hline 16 & Benzo[e]pyrene & 252 \\
\hline 17 & Benzo[a]pyrene & 252 \\
\hline 18 & Perylene & 252 \\
\hline 19 & 3-Methylcholanthrene & 268 \\
\hline 20 & Indeno[1,2,3-cd]pyrene & 276 \\
\hline 21 & Benzo[g,h,i]perylene & 276 \\
\hline
\end{tabular}

1986; Zone-2: Srivastava and Sarate 1989), Wardha Coalfield (Assemblage-B: Bhattacharyya 1997), Talcher Coalfield (Assemblage-II: Tripathi 1997), and Sohagpur Coalfield (Palynozone-2: Meena 2000; Palyno assemblage-I: Ram-Awatar et al., 2003). These palynoassemblage correlations suggest that the sediment of borehole RMB\#2 in Rajmahal Basin can be dated as Early Permian (Artinskian).

The presence of homogenized cell walls and wellpreserved anatomical features in the samples confirms that the analyzed woody fragments are fossil charcoal and thus they can be used as direct indicators for the incidence of palaeo-wildfires (Jones and Chaloner 1991; Scott 2010). Furthermore, the identification of macroscopic charcoal fragments in the two shale samples provides indications for repeated wildfires during the deposition of the studied rock segment. The abundance, large size, well-preserved anatomical features, and nonabraded edges of the recovered macroscopic charcoal fragments indicate that these fragments were possibly only transported over a very short distance before they were deposited (Scott 2000; Abu Hamad et al. 2012; Jasper et al. 2016), suggesting a parautochthonous/autochthonous origin. All the charcoal fragments show anatomical structures of a gymnospermous affinity. A number of gymnosperm groups present in the source vegetation (e.g., Prevec et al. 2009; Philippe 2011), like different conifer families and glossopterids, are anatomically comparable to the charcoal described here. Thus, it is not possible to decide more specifically which of these gymnosperm groups were affected by the wildfires, based on anatomy alone. The sporadic occurrence of charcoal in the stratigraphic succession indicates that the wildfire was a usual event somewhere in the catchment area. The occurrence of fungal remains, and the modification of cell walls (i.e. "shot-like holes") can probably be interpreted as evidence for pre-charring decay (cf. El Atfy et al. 2019; Uhl et al. 2020). However, it is not possible to conclude whether this decay occurred in living plant parts or in died off, but still attached, parts of living trees, in which case the charcoal could have been produced by a crown fire, or occurred in litter covering the ground, in which case it would indicate a ground or surface fire (cf. El Atfy et al. 2019; Uhl et al. 2020; and citations therein).

Owing to their highly recalcitrant nature, $n$-alkanes constitute one of the maximum resistant biomarkers and the most encouraging indicators for the source of the organic matter. Moreover, the distribution of $n$-alkanes ranges between $n-C_{14}$ and $n-C_{31}$ showing a bimodal 


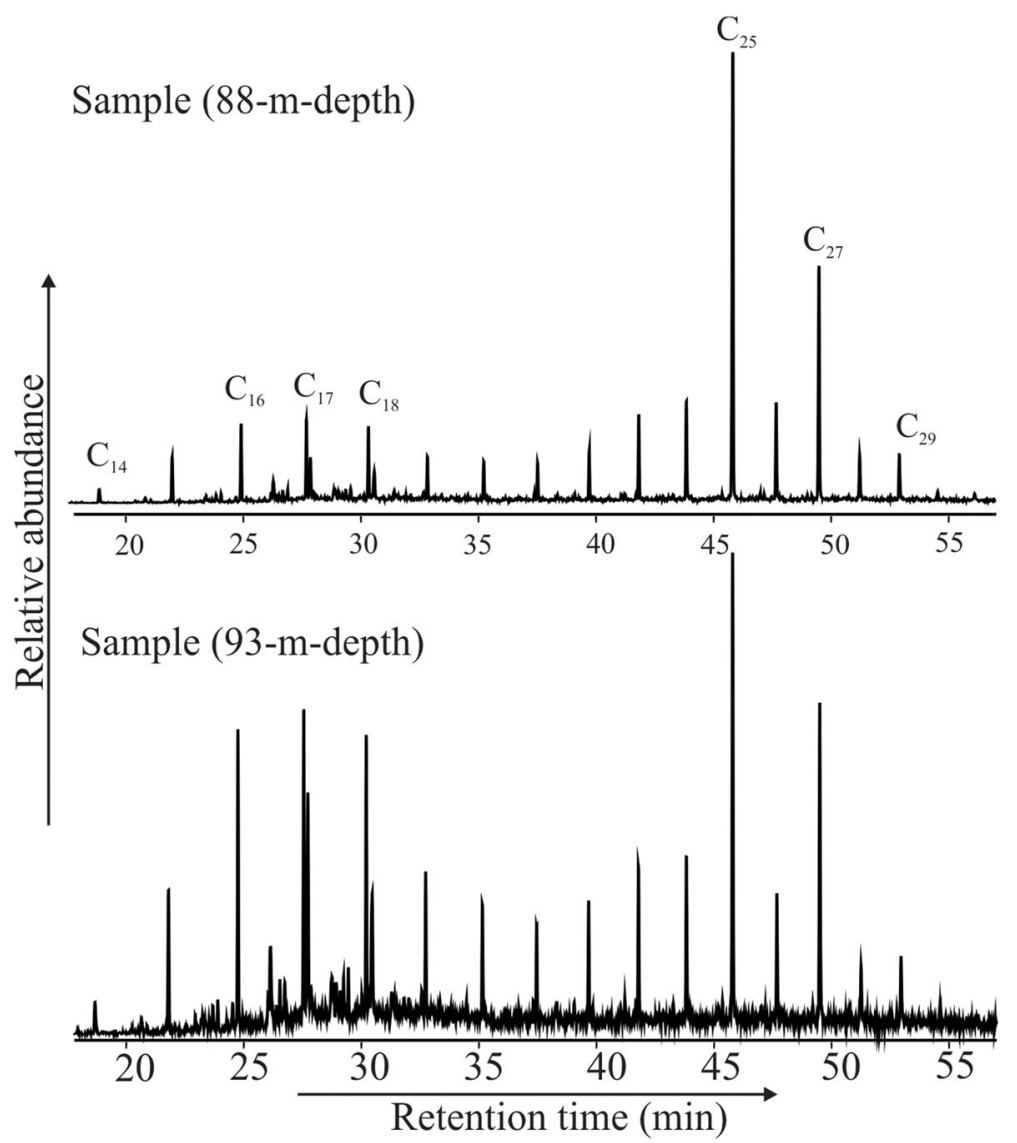

Fig. 10 The $n$-alkane distribution in the two studied charcoal-bearing samples from $88-m$ - and $93-m$-depth of borehole RMB\#2 in the Rajmahal Basin

distribution pattern in the studied samples. The abundance of short-chain $n-C_{16}$ to $n-C_{18}$ compounds can be attributed to an input from lower organisms (Cranwell 1984). An algal source of organic matter is indicated by the ascendency of $n-C_{17}$ whereas a bacterial source is indicated by the copious $n-C_{16}$ to $n-C_{18}$ alkane homologues. The predominance of $n$-alkane homologues with longer chain length $\left(n-C_{25}\right.$ and $\left.n-C_{27}\right)$ in the studied samples suggests input from higher plant sources (Eglinton and Hamilton 1967).

The carbon preference index (CPI) values for the samples are larger than 1 (3.35 and 2.56) and indicate major input of higher plant-derived organic matter into the sediments. The acyclic isoprenoid hydrocarbons, pristane $(\mathrm{Pr})$ and phytane $(\mathrm{Ph})$, are observed in the samples with a predominance of pristane. The $\mathrm{Pr} / \mathrm{Ph}$ ratio is widely used to describe the palaeo-redox setting in depositional environments (e.g. Didyk et al. 1978; Hughes et al. 1995). However, this ratio must be used with caution as it is known to change with increasing diagenesis (Ten Haven et al. 1987). The estimated $\mathrm{Pr} / \mathrm{Ph}$ ratio for the studied samples is 1.38 and 1.73 respectively, suggesting suboxic conditions.
Diterpenoid is the fragment of essential oils and a resinous substance formed by conifers and other gymnosperms, hence diterpenoids can be considered as reliable biomarkers for the occurrence of this plant group. The diterpenoids identified in the studied samples are compounds of pimarane, phyllocladane and abietane type along with some unidentified compounds. Pimarane compounds are noticed commonly among conifer families (Otto and Wilde 2001). Phyllocladanes can be produced by species of four different conifer families, and thus, using the phyllocladane to identify an individual family is very difficult. Nevertheless, as phyllocladane cannot be produced by Pinaceae, it may point to Conifers other than Pinaceae (Otto et al. 1997). Abietane compounds including Dehydroabietane, 18-/19-Norabieta-4(19),8,11,13-tetraene (?) along with Simonellite were recognized in the samples. These compounds are often considered as biomarkers for Pinaceae, as abietic acid is a characteristic compound of this family (Simoneit 1977; Laflamme and Hites 1978; Barnes and Barnes 1983; Simoneit et al. 1986). However, Dehydroabietane and Simonellite are also possibly derived from abietane-type precursors such as taxodone and ferruginol is also produced by taxodioid 
<smiles>CC[C@]1(C)CCC2C(CCC3C(C)CCC[C@]32C)C1</smiles>

18-Norpimarane<smiles>Cc1cccc2c1ccc1cc(C(C)C)ccc12</smiles>

Retene

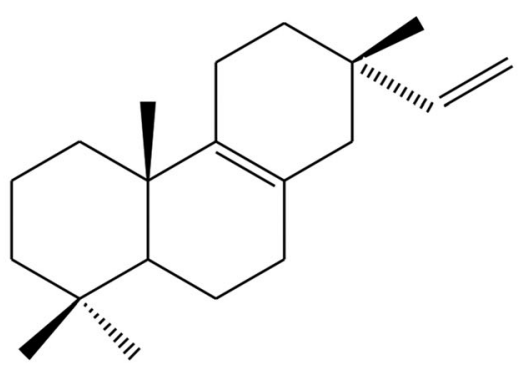

Sandaracopimaradiene

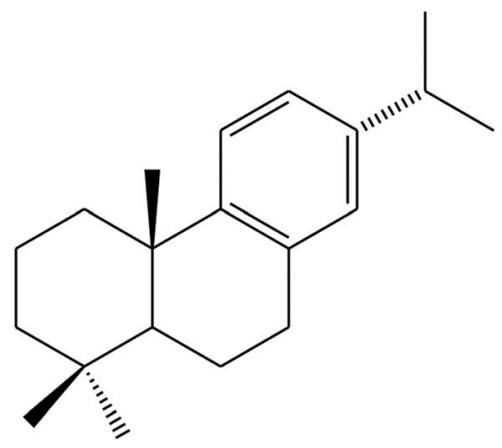

Dehydroabietane

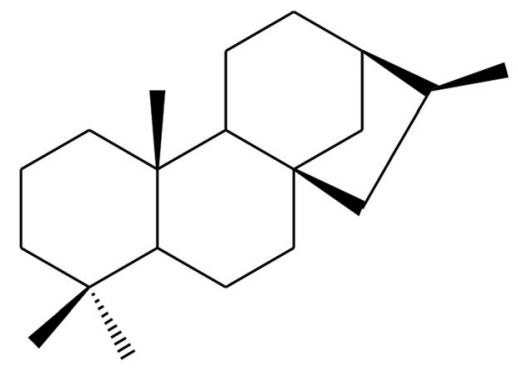

16a(H)-Phyllocladane<smiles>CC(C)c1ccc2c3c(ccc2c1)C(C)(C)CCC3</smiles>

Simonellite

Fig. 11 The diterpenoid compounds identified in the two charcoal-bearing samples from 88-m- and 93-m-depth of borehole RMB\#2 in the Rajmahal Basin

Cupressaceae (Otto et al. 1997). Retene is a notable aromatic diterpenoid identified in these samples. The presence of Retene may point to the thermal degradation of resin compounds during wood combustion (Ramdahl 1983). Therefore, this study suggests that the source flora responsible for the charcoal could possibly be early conifers, whereas other gymnosperm groups, e.g. glossopterids, are considered as an unlikely source, despite their anatomical similarity. Pentacyclic hopanoid triterpenoid compounds, considered to be derived from bacteriohopanetetrol and/or 3-desoxy-hopane (Ourisson et al. 1979; Rohmer et al. 1992), have also been identified in the studied samples. Generally, the distribution of hopanes indicates aerobic bacterial degradation of organic matter. The profusion of hopanoids indicates a significant bacterial input to the sediment. Sterenes, steranes and diasteranes are either absent or present in traces, which may also suggest intensive bacterial reworking of sedimentary organic matter (Marynowski and Zatoń 2010).

Due to their pyrogenic origin, unsubstituted polycyclic aromatic hydrocarbons (PAHs) may indicate forest fires and are widely used in the reconstruction of palaeoenvironments (e.g. Venkatesan and Dahl 1989; Killops and Massoud 1992; Finkelstein et al. 2005; Marynowski and Simoneit 2009; Scott et al.
2010), although other sources have also been identified (e.g. Basile et al. 1984; Kawka and Simoneit 1990; George 1992; Simoneit and Fetzer 1996; Jiang et al. 2000; Naraoka et al. 2000; Marynowski et al. 2002; Sephton et al. 2005; Grice et al. 2007; Rospondek et al. 2007). However, higher concentration of PAHs and the co-occurrence with charcoal fragments undoubtedly suggest wildfires (e.g., Finkelstein et al. 2005; Marynowski and Simoneit 2009; Scott et al. 2010; Kubik et al. 2020). Besides the unsubstituted PAHs, oxygen- and phenyl-containing polycyclic aromatic compounds are also present but rarely identified (Marynowski and Simoneit 2009). Oxygencontaining dibenzofuran is identified with negligible abundance. However, methyldibenzofuran is relatively abundant. The identified phenyl-containing compounds are phenylphenanthrene and phenyldibenzofuran. Phenyl derivatives of PAHs represented by phenylnaphthalenes and phenylphenanthrenes are products of pyrolytic rather than biogenic processes (Kubik et al. 2020). The presence of hydrocarbons such as anthracene possibly suggests their hightemperature formation (Marynowski et al. 2014). In a word, the occurrence of charcoal with PAHs and high plant biomarkers including Retene can indicate 


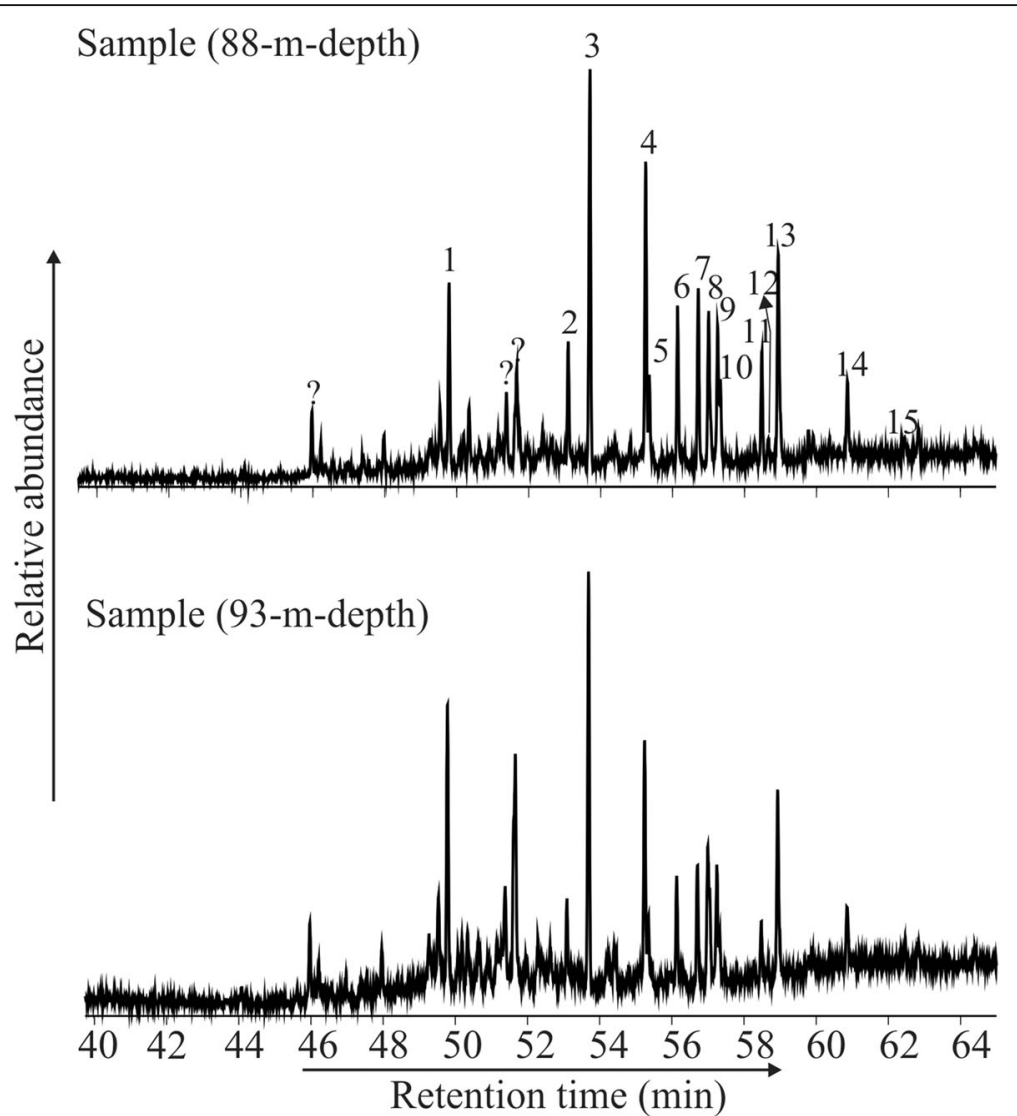

Fig. 12 Pentacyclic triterpenoid distribution in the two charcoal-bearing samples from 88-m- and 93-m-depth of borehole RMB\#2 in the Rajmahal Basin

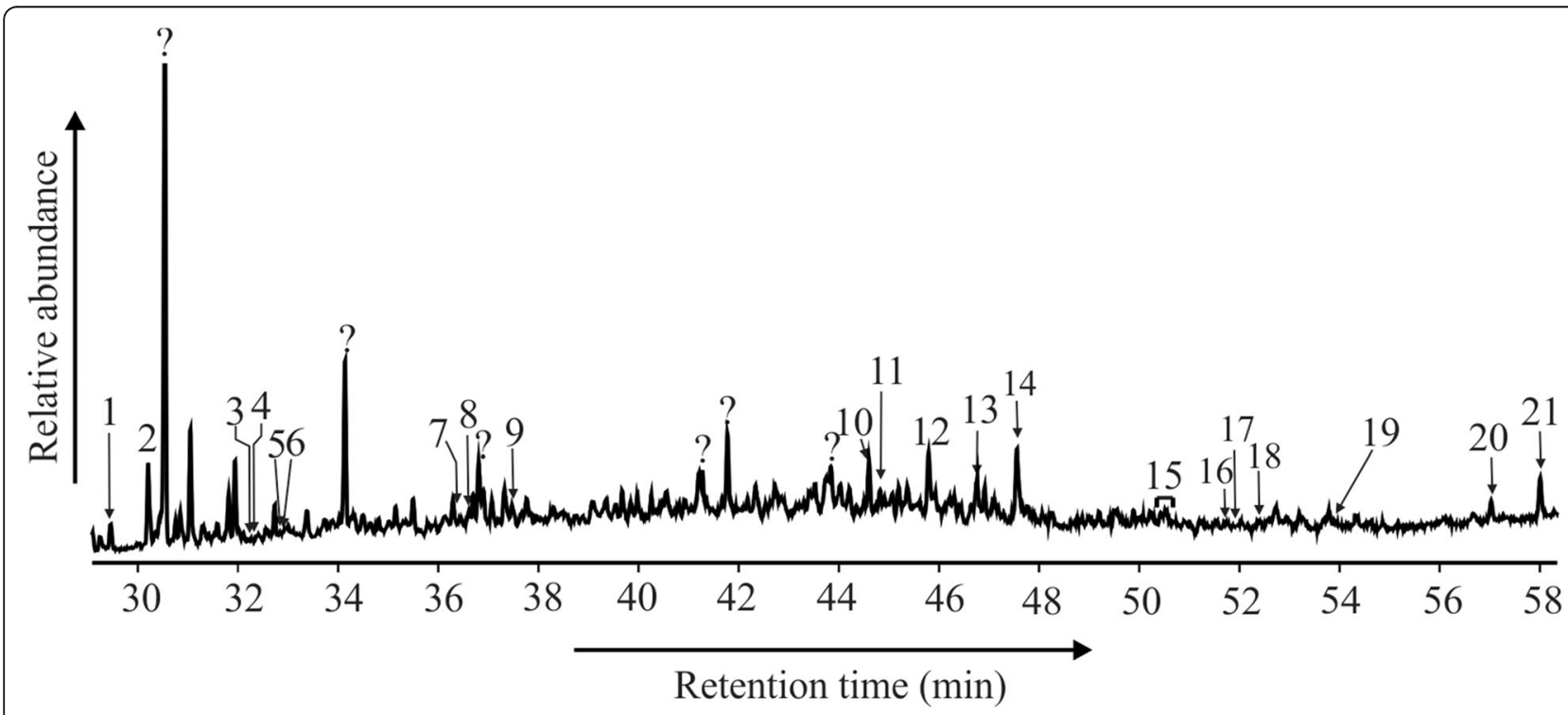

Fig. 13 Distribution of the polyaromatic hydrocarbon (PAH) compounds in the two charcoal-bearing samples from 88-m- and 93-m-depth of borehole RMB\#2 in the Rajmahal Basin 
possible wildfire events causing the charring of wood, which has subsequently been integrated into the sediments.

\section{Conclusions}

1) Identification of the Scheuringipollenites barakarensis palynoassemblage in charcoal-bearing carbonaceous shales from the borehole RMB\#2 of the Dhulia Coal Block, Rajmahal Basin, India leads to the assignment of an Early Permian (Artinskian) age.

2) Charcoal fragments exhibit anatomical details such as homogenized cell walls, uniseriate simple, biseriate alternate pitting patterns and rays of one-cell-height on tracheid walls of charcoal fragments, and the presence of diterpenoid compounds in sediments containing charcoal fragments point to their gymnospermous affinity.

3) The occurrence of higher plant biomarkers along with PAHs at different depths of the borehole RMB\#2 demonstrates repetitive incidences of wildfire events during deposition of the Barakar sediments.

\begin{abstract}
Acknowledgements
The authors are grateful to the Director of the Birbal Sahni Institute of Palaeosciences for his kind permission to publish this work (RDCC Permission Number 10/2020-2021). The authors are thankful to the Director of the CSIRCIMFR for granting and extending the laboratory facility. The Geological Survey of India (GSI), Kolkata is acknowledged for the valuable supports in field sampling and in accessing detailed geological information. The authors are also thankful to Prof. Zeng-Zhao Feng, Prof. Mihai Emilian Popa, Prof. Franz Fürsich and an anonymous reviewer for their constructive suggestions, which improved the quality of this research article.
\end{abstract}

\section{Authors' contributions}

SM conducted the sample collection, photography, data analysis, work design, and manuscript preparation; VAM provided the borehole location of samples, identified lithology of the section, and improved the manuscript; DU improved the manuscript, especially the fossil charcoal part as well as in improving language; RPM carried out the sample preparation, analysis, and the geochemical (biomarker) interpretation of charcoal; VKM prepared the location map and participated in the sample collection; SG prepared for the sample maceration and the lithological photography. All authors read and approved the final paper.

\section{Funding}

This study was funded by the Birbal Sahni Institute of Palaeosciences, Department of Science and Technology, Lucknow, India Research Development and Coordination Committee (RDCC; Permission Number 10/ 2020-2021).

\section{Availability of data and materials}

The data and material are available in the Birbal Sahni Institute of Palaeosciences, Department of Science and Technology, Lucknow, India.

\section{Competing interests}

The authors declare that they have no competing interests.

\section{Author details}

${ }^{1}$ Birbal Sahni Institute of Palaeosciences, 53, University Road, Lucknow 226007, India. ${ }^{2}$ CSIR-Central Institute of Mining and Fuel Research, Dhanbad, Jharkhand 826015, India. ${ }^{3}$ Senckenberg Forschungsinstitut und Naturmuseum Frankfurt, Senckenberganlage 25, 60325 Frankfurt am Main Germany.
Received: 26 June 2020 Accepted: 22 January 2021

Published online: 02 March 2021

\section{References}

Abu Hamad, A.M.B., A. Jasper, and D. Uhl. 2012. The record of Triassic charcoal and other evidence for palaeo-wildfires: Signal for atmospheric oxygen levels, taphonomic bias or lack of fuel? International Journal of Coal Geology 96-97: 60-71.

Baksi, A.K., R.S. Tiwari, A. Tripathi, and E. Farrar. 1992. Geochemical geochronological and palynological observations on lower-cretaceous lavas in the Rajmahal Basin. Abstracts from the National Symposium on Mesozoic magmatism of the eastern margin of India, Patna, 16-17. University of Patna.

Ball, V. 1877. Geology of the Rajmahal Hills. Memoir Geological Survey India 13: $155-248$.

Balme, B.E. 1995. Fossil in situ spores and pollen grains: An annotated catalogue. Review of Palaeobotany and Palynology 87: 81-323.

Banerjee, M., and A. D'Rozario. 1988. Biostratigraphy and environment of deposition in the lower Gondwana sediments of Chuperbhita coalfield, Rajmahal Hills. Journal of the Palaeontological Society of India 33: 73-90.

Banerjee, M., and A. D'Rozario. 1990. Palynostratigraphic correlation of lower Gondwana sediments in the Chuparbhita and Hura basins, Rajmahal Hills, East India. Review of Palaeobotany and Palynology 65: 239-255.

Banerji, J. 1993. Plant fossils from Chunakhal, Rajmahal Hills, Bihar. Geophytology 23: 21-80.

Banerji, J. 1995. Recent records of Mesozoic ferns from Rajmahal Basin. Indian Fern Journal 12: 70-78.

Banerji, J. 2000. Megafloral diversity of the upper Gondwana sequence of the Rajmahal Basin, India. Journal of African Earth Science 31: 133-144.

Banerji, J., and B.N. Jana. 1998. Early Cretaceous megafossils from Balidih, Rajmahal Basin, India. Geophytology 27: 33-36.

Barnes, M.A., and W.C. Barnes. 1983. Oxic and anoxic diagenesis of diterpenes in lacustrine sediments. In:Bjoroy, M., P. Albrecht, C. Cornford, K. de Groot, G. Eglinton, E. Jalimer, D. Leytheruser, R. Polet, J.Rulltitter, and G. Speers. (Eds.). Advances in Organic Geochemistry 1981. Wiley, Chichester: pp. 289-298.

Basile, B.P., B.S. Middleditch, and J. Oró. 1984. Polycyclic aromatic hydrocarbons in the Murchison meteorite. Organic Geochemistry 5: 211-216.

Belcher, C.M., L. Mander, G. Rein, F.X. Jervis, M. Haworth, S.P. Hesselbo, I.J. Glasspool, and J.C. McElwain. 2010. Increased fire activity at the Triassic/ Jurassic boundary in Greenland due to climate-driven floral change. Nature Geoscience 3: 426-429.

Benício, J.R.W., A. Jasper, R. Spiekermann, L. Garavaglia, E.F. Pires-Oliveira, N.T. G. Machado, and D. Uhl. 2019. Recurrent palaeo-wildfires in a Cisularian coal seam: A palaeobotanical view on high-inertinite coals from the lower Permian of the Paraná Basin, Brazil. PLoS One 14: e0213854.

Bhattacharyya, A.P. 1997. Palynological recognition of the Karharbari-Barakar formation in the sub-surface sediments of Wardha coalfield, Maharashtra, India. Palaeobotanist 46: 217-219.

Bond, W.J., and A.C. Scott. 2010. Fire and the spread of flowering plants in the Cretaceous. New Phytologist 188: 1137-1150.

Bowman, D.M.J.S., J.K. Balch, P. Artaxo, W.J. Bond, J.M. Carlson, M.A. Cochrane, C.M. D'Antonio, R.S. Defries, J.C. Doyle, S.P. Harrison, F.H. Johnston, J.E. Keeley, M.A. Krawchuk, C.A. Kull, J.B. Marston, M.A. Moritz, I. C. Prentice, C.I. Roos, A.C. Scott, T.W. Swetnam, G.R. van der Werf, and S. J. Pyne. 2009. Fire in the Earth system. Science 324: 481-484.

Bray, E.E., and E.D. Evans. 1961. Distribution of $n$-paraffins as a clue to recognition of source beds. Geochimica et Cosmochimica Acta 22: 2-15.

Cranwell, P.A. 1984. Lipid geochemistry of sediments from Upton Broad, a small productive lake. Organic Geochemistry 7: 25-37.

Daniel, G. 2003. 4. Microview of wood under degradation by bacteria and fungi. In: Goodell, B., D.D. Nicholas,T.P. Schultz. (Eds.). Wood Deterioration and Preservation. ACS Symposium Series No. 845, 2003: pp. 34-72.

Denis, E.H., J.H. Toney, R. Tarozo, R.S. Anderson, L.D. Roach, and Y. Huang 2012. Polycyclic aromatic hydrocarbons (PAHs) in lake sediments record historic fire events: Validation using HPLC-fluorescence detection. Organic Geochemistry 45: 7-17. 
di Pasquo, M.M., and G.W. Grader. 2012. The palynology of the lower Permian (Asselian-?Artinskian) Copacabana Formation of Apillapampa, Cochabamba, Bolivia. Palynology 36: 264-276.

Didyk, B.M., B.R.T. Simoneit, S.C. Brassell, and G. Eglinton. 1978. Organic geochemical indicators of paleoenvironmental conditions of sedimentation. Nature 272: 216-222.

Eglinton, G., and R.J. Hamilton. 1967. Leaf epicuticular waxes. Science 156: 1322-1334.

El Atfy, H., P. Havlik, P.S. Krüger, J. Manfroi, A. Jasper, and D. Uhl. 2019. Prequaternary wood decay 'caught in the act' by fire - Examples of plant-microbe interactions preserved in charcoal from clastic sediments. Historical Biology 31: 952-961.

Finkelstein, D.B., L.M. Pratt, T.M. Curtin, and S.C. Brassell. 2005. Wildfires and seasonal aridity recorded in late Cretaceous strata from south-eastern Arizona, USA. Sedimentology 52: 587-599.

Flannigan, M.D., M.A. Krawchuk, W.J. de Groot, B.M. Wotton, and L.M. Gowman. 2009. Implications of changing climate for global wildland fire. International Journal of Wildland Fire 18: 483-507.

George, S.C. 1992. Effect of igneous intrusion on the organic geochemistry of a siltstone and an oil shale horizon in the Midland Valley of Scotland. Organic Geochemistry 18: 705-723.

Ghosh, A.K., S.P. Roy, and T. Laskar. 1984. Biostratigraphy and some anamolous petrological properties of Chuparbhita coals, Rajmahal coalfields, Bihar. Evolutionary botany and biostratigraphy, A.K. Ghosh Commemoration Volume, 323-330.

Glasspool, I.J., D. Edwards, and L. Axe. 2004. Charcoal in the Silurian as evidence for the earliest wildfire. Geology 32: 381-383.

Grice, K., B. Nabbefeld, and E. Maslen. 2007. Source and significance of selected polycyclic aromatic hydrocarbons in sediments (Hovea-3 well, Perth Basin, Western Australia) spanning the Permian-Triassic boundary. Organic Geochemistry 38: 1795-1803.

Hughes, W.B., A.G. Holba, and L.I.P. Dzou. 1995. The ratios of dibenzothiophene to phenanthrene and pristane to phytane as indicators of depositional environment and lithology of petroleum source rocks. Organic Geochemistry 17: 3581-3598.

Jasper, A., D. Agnihotri, R. Tewari, R. Spiekermann, E.F. Pires, A.A.S. Da Rosa, and D. Uhl. 2017. Fires in the mire: Repeated fire events in early Permian 'peat forming' vegetation of India. Geological Journal 52: 955-969.

Jasper, A., M. Guerra-Sommer, A.M.B. Abu Hamad, M. Bamford, M.E.C. Bernardes-de-Oliveira, R. Tewari, and D. Uhl. 2013. The burning of Gondwana: Permian fires on the southern continent - A palaeobotanical approach. Gondwana Research 24: 148-160.

Jasper, A., M. Guerra-Sommer, D. Uhl, M.E.C. Bernardes-de-Oliveira, A.K. Ghosh, R. Tewari, and M.I. Secchi. 2012. Palaeobotanical evidence of wildfires in the upper Permian of India: Macroscopic charcoal remains from the Raniganj Formation, Damodar Valley Basin. Palaeobotanist 61: $75-82$

Jasper, A., D. Uhl, D. Agnihotri, R. Tewari, S.K. Pandita, J.R.W. Benício, E.F. Pires, A.S. Da Rosa, G.D. Bhat, and S.K. Pillai. 2016. Evidence of wildfires in the late Permian (Changsinghian) Zewan Formation of Kashmir, India. Current Science 110: 419-423.

Jha, N., and N. Aggarwal. 2010. Palynostratigraphy and correlation of lower Gondwana coal-bearing and associated sediments in Satrajpalli area, Godavari graben, Andhra Pradesh. Journal of the Palaeontological Society of India 55: 147-155.

Jha, N., and N. Aggarwal. 2011. Palynological correlation of coal-bearing horizons in Gundala area, Godavari Graben, India. Journal of Earth System Science 120: 663-679.

Jha, N., and N. Aggarwal. 2012. Permian-Triassic palynostratigraphy in Mailaram area, Godavari Graben, Andhra Pradesh, India. Journal of Earth System Science 121 (5): 1257-1285.

Jha, N., and N. Aggarwal. 2015. Peat forming environment of coal-bearing Permian sediments in Kanchinapalli area of Godavary Graben, India. Revista Brasileira de Paleontologia 18 (2): 239-250.

Jiang, C., R. Alexander, R.I. Kagi, and A.P. Murray. 2000. Origin of perylene in ancient sediments and its geological significance. Organic Geochemistry 31: $1545-1559$.
Jones, T.P., and W.G. Chaloner. 1991. Fossil charcoal, its recognition and palaeoatmospheric significance. Palaeogeography, Palaeoclimatology, Palaeoecology 97: 39-50.

Kawka, O.E., and B.R.T. Simoneit. 1990. Polycyclic aromatic hydrocarbons in hydrothermal petroleums from theGuaymas Basin spreading center. In: Simoneit, B.R.T. (Ed.). Organic Matter Alteration in Hydrothermalsystems: Petroleum Generation, Migration and Biogeochemistry. Applied Geochemistry 5: pp. 17-27.

Killops, S.D., and M.S. Massoud. 1992. Polycyclic aromatic hydrocarbons of pyrolytic origin in ancient sediments: Evidence for Jurassic vegetation fires. Organic Geochemistry 18: 1-7.

Kubik, R., L. Marynowski, D. Uhl, and A. Jasper. 2020. Co-occurrence of charcoal, polycyclic aromatic hydrocarbons and terrestrial biomarkers in an early Permian swamp to lagoonal depositional system, Paraná Basin, Rio Grande do Sul, Brazil. International Journal of Coal Geology 230: 103590.

Kubik, R., D. Uhl, and L. Marynowski. 2015. Evidence of wildfires during deposition of the upper Silesian Keuper succession. Annales Societatis Geologorum Poloniae 85: 685-696.

Laflamme, R.E., and R.A. Hites. 1978. The global distribution of polycyclic aromatic hydrocarbons in recent sediments. Geochimica et Cosmochimica Acta 42: 289-303.

Lindström, S., and S. McLoughlin. 2007. Synchronous palynofloristic extinction and recovery after the end-Permian event in the Prince Charles Mountains, Antarctica: Implications for palynofloristic turnover across Gondwana. Review of Palaeobotany and Palynology 145: 89-122.

MacDonald, G.M., C.P.C. Larsen, J.M. Szeicz, and K.A. Moser. 1991. The reconstruction of boreal forest fire history from lake sediments - A comparison of charcoal, pollen, sedimentological, and geochemical indexes. Quaternary Science Review 10: 53-71.

Mahesh, S., S. Murthy, B. Chakraborty, and M.D. Roy. 2015. Fossil charcoal as Palaeofire indicators: Taphonomy and morphology of charcoal remains in sub-surface Gondwana sediments of south Karanpura coalfield. Journal of Geological Society of India 85: 567-576.

Mahesh, S., S. Murthy, S. Gautam, P.A. Souza, P.S. Kavali, M.E.C. Bernardes-deOliveira, Ram Awatar, and C.M. Félix. 2017. Macroscopic charcoal remains as evidence of wildfire from late Permian Gondwana sediments of India: Further contribution to global fossil charcoal database. Palaeoworld 26 (4): 638-649.

Maheshwari, H.K. 1967. Studies in the Glossopteris Flora of India - 29. Miospore assemblage from the lower Gondwana exposures along Bansloi River in Rajmahal Hills, Bihar. Palaeobotanist 15: 258-280.

Marynowski, L., R. Kubik, D. Uhl, and B.R.T. Simoneit. 2014. Molecular composition of fossil charcoal and relationship within complete combustion of wood. Organic Geochemistry 77: 22-31.

Marynowski, L., M.J. Rospondek, R. Meyer, Z.U. Reckendorf, and B.R.T Simoneit. 2002. Phenyldibenzofurans and phenyldibenzothiophenes in marine sedimentary rocks and hydrothermal petroleum. Organic Geochemistry 33: 701-714

Marynowski, L., A.C. Scott, M. Zaton, H. Parent, and A.C. Garrido. 2011. First multiproxy record of Jurassic wildfires from Gondwana: Evidence from the middle Jurassic of the Neuquen Basin, Argentina. Palaeogeography Palaeoclimatology Palaeoecology 299: 129-136.

Marynowski, L., and B.R.T. Simoneit. 2009. Widespread late Triassic to early Jurassic wildfire records from Poland: Evidence from charcoal and pyrolytic polycyclic aromatic hydrocarbons. Palaios 24: 785-798.

Marynowski, L., and M. Zatoń. 2010. Organic matter from the Callovian (middle Jurassic) deposits of Lithuania: Compositions, sources and depositional environments. Applied Geochemistry 25 (7): 933-946.

Meena, K.L. 2000. Palynodating of subsurface sediments of bore-hole IBH-6 in IB River coalfield, Orissa, India. Geophytology 29: 111-113.

Mishra, S., N. Aggarwal, and N. Jha. 2017. Palaeoenvironmental change across the Permian-Triassic boundary inferred from palynomorph assemblages (Godavari Graben, South India). Palaeobiodiversity and Palaeoenvironments 98 (2): 177-204. https:/doi.org/10.1007/s12549-017-0302-3.

Murthy, S., Ram Awatar, and S. Gautam. 2014. Palynostratigraphy of Permian succession in the Mand-Raigarh coalfield, Chhattisgarh, India. Journal of Earth System Science 123 (8): 1879-1893. 
Murthy, S., B. Chakraborthi, and M.D. Roy. 2010. Palynodating of subsurface sediments, Raniganj coalfield, Damodar Basin, West Bengal. Journal of Earth System Sciences 119 (5): 701-710.

Murthy, S., P.S. Kavali, M. Di Pasquo, and B. Chakraborti. 2018. Late Pennsylvanian and early Cisuralian palynofloras from the Rajmahal Basin, eastern India, and their chronological significance. Historical Biology 32 (2): 143-159. https://doi.org/10.1080/08912963.2018.1529763.

Naraoka, H., A. Shimoyama, and K. Harada. 2000. Isotopic evidence from an Antarctic carbonaceous chondrite for two reaction pathways of extraterrestrial PAH formation. Earth Planet Science Letters 184: 1-7.

Otto, A., H. Walther, and W. Püttmann. 1997. Sesqui- and diterpenoidbiomarkers preserved in Taxodium-rich Oligocene oxbow lake clays, Weisselster Basin, Germany. Organic Geochemistry 26 (1-2): 105-115.

Otto, A., and V. Wilde. 2001. Sesqui-, di- and triterpenoids as chemosystematic markers in extant conifers - A review. Botanical Review 67: 141-238.

Ourisson, G., P. Albrecht, and M. Rohmer. 1979. The Hopanoids: Palaeochemistry and biochemistry of a group of natural products. Pure and Applied Chemistry 51 (4): 709-729. https://doi.org/10.1351/ pac197951040709.

Philippe, M. 2011. How many species of Araucarioxylon? Comptes Rendus Palevol 10 (2-3): 201-208.

Prakash, Anand, and S.C. Srivastava. 1984. Miofloral studies of the lower Gondwana sediments in Johilla coalfield, Madhya Pradesh, India. Palaeobotanist 32 (3): 243-252.

Prevec, R., C.C. Labandeira, J. Neveling, R.A. Gastaldo, C.V. Looy, and M. Bamford. 2009. Portrait of a Gondwanan ecosystem: A new late Permian fossil locality from KwaZulu-Natal, South Africa. Review of Palaeobotany and Palynology 156: 454-493.

Raja Rao, C.S. 1987. Coal resources of Bihar (excluding Dhanbad District). Bulletin Geological Survey India Series 45 (IV): 300-322.

Ram-Awatar, A. Mukhopadhyay, and S. Adhikari. 2003. Palynostratigraphy of sub surface lower Gondwana, Pali sediments, Sohagpur coalfield, Madhya Pradesh, India. Palaeobotanist 53: 51-59.

Ramdahl, T. 1983. Retene: A molecular marker of wood combustion in ambient air. Nature 306: 580-582.

Rao, A.R. 1943. Jurassic spores and sporangia from the Rajmahal Hills, Bihar. Proceedings National Academy Science of India (B) 13 (6): 181-197.

Rohmer, M., P. Bisseret, and S. Neunlist. 1992. The hopanoids, procaryotic triterpenoids and precursors ofubiquitous molecular fossils. In: Moldowan, J.M., P. Albrecht, and R.P. Philp. (Eds.). Biological Markers inSediments and Petroleum. Prentice Hall, Engle wood Cliffs, New Jersey: pp. 1-17.

Rospondek, M.J., L. Marynowski, A. Chachaj, and M. Góra. 2007. Novel arylated polycyclic aromatic thiophenes: Phenylnaphtho [b] thiophenes and naphthylbenzo $[\mathrm{b}]$ thiophenes as markers of the organic matter oxidation by rock-water interaction. Organic Geochemistry 38: 1729-1756.

Sander, P.M., and C.T. Gee. 1990. Fossil charcoal: Techniques and applications. Review of Palaeobotany and Palynology 63: 269-279.

Sarate, O.S. 1986. Palynological correlation of the coal seams of Pathakhera coalfield, Madhya Paradesh, India. Geophytology 16: 239-248.

Schwarze, F.W.M.R. 2007. Wood decay under the microscope. Fungal Biology Reviews 21: 133-170.

Schweingruber, F.H. 1990. Mikroskopische Holzanatomie - Formenspektren mitteleuropäischer Stamm - und Zweighölzer zur Bestimmung von rezentem und subfossilem Material. 3rd Edition. Eidg Forschungsanstalt für Wald, Schnee und Landschaft. Birmensdorf, 226.

Schweingruber, F.H., A. Börner, and E.D. Schulze. 2006. Atlas of Woody Plant stems: Evolution, structure, and environmental modifications, 229. Schmidt \& Vöckler GbR, Leipzig, Germany: LE-TeX Jelonek. https://doi.org/10. 1007/978-3-540-32525-3.

Scott, A.C. 1989. Observations on the nature and origin of fusain. International Journal of Coal Geology 12: 443-475.

Scott, A.C. 2000. The pre-Quaternary history of fire. Palaeogeography, Palaeoclimatology, Palaeoecology 164: 281-329.

Scott, A.C. 2010. Charcoal recognition, taphonomy and uses in palaeoenvironmental analysis. Palaeogeography, Palaeoclimatology, Palaeoecology 291: 11-39.
Scott, A.C., B.M.J.S. Bowman, W.J. Bond, S.J. Pyne, and M.E. Alexander. 2014 Fire on Earth: An Introduction.Wiley Blackwell: 413 pp.

Scott, A.C., and I. Glasspool. 2006. The diversification of Paleozoic fire systems and fluctuations in atmospheric oxygen concentration. Proceedings of the National Academy of Sciences 103 (29): 10861-10865.

Scott, A.C., and T.P. Jones. 1994. The nature and influence of fires in Carboniferous ecosystems. Palaeogeography, Palaeoclimatology, Palaeoecology 106: 91-112.

Scott, A.C., F. Kenig, R.E. Plotnick, I.J. Glasspool, W.G. Chaloner, and C.F. Eble. 2010. Evidence of multiple late Bashkirian to early Moscovian (Pennsylvanian) fire events preserved in contemporaneous cave fills. Palaeogeography, Palaeoclimatology, Palaeoecology 291: 72-84.

Sengupta, S. 1988. Upper Gondwana stratigraphy and palaeobotany of Rajmahal Hills, Bihar, India. Memoirs of the Geological Survey of India, Palaeontologia Indica 48: 1-180.

Sephton, M.A., G.D. Love, W. Meredith, C.E. Snape, C.G. Sun, and J.S. Watson. 2005. Hydropyrolysis: A new technique for the analysis of macromolecular material in meteorites. Planetary Space Science 53: 1280-1286.

Sharma, B.D. 1967. Investigations on the Jurassic flora of Rajmahal Hills, India. 3. A review of the genus Ptilophyllum of Morris, with description of two new species from Amarjola in the Rajmahal Hills. Palaeontographica (B) 120: 139-150.

Sharma, B.D. 1969. On a collection of fossil fern from Dhokuti in the Rajmahal Hills, India. Palaeontographica B 128: 55-63.

Sharma, B.D. 1974. Ovule ontogeny in Williamsonia Carr. Palaeontographica B 148: 137-143.

Sharma, B.D. 1997. An early angiosperm fructification resembling Lesqueria Crane and Dilcher from the Rajmahal Hills, India. Phytomorphology 47: 305-310.

Simoneit, B.R.T. 1977. Diterpenoid compounds and other lipids in deep-sea sediments and their geochemical significance. Geochimica et Cosmochimica Acta 41: 463-476.

Simoneit, B.R.T., and J.C. Fetzer. 1996. High molecular weight polycyclic aromatic hydrocarbons in hydrothermal petroleums from the Gulf of California and Northeast Pacific Ocean. Organic Geochemistry 24: 1065-1077.

Simoneit, B.R.T., J.O. Grimalt, T.G. Wang, R.E. Cox, P.G. Hatcher, and A. Nissenbaum. 1986. Cyclic terpenoids of contemporary resinous plant detritus and of fossil woods, ambers and coal. Organic Geochemistry 10: 877-889.

Singh, A.P., Y.S. Kim, and T. Singh. 2016. Bacterial degradation of wood. In Secondary xylem biology, ed. Y.S. Kim, R. Funada, and A.P. Singh, 169190. Cambridge: Academic Press.

Srivastava, S.C., and Anand-Prakash. 1984. Palynological succession of the lower Gondwana sediments in Umaria coalfield, Madhya Pradesh, India. Palaeobotanist 32 (1): 26-34.

Srivastava, S.C., and H.K. Maheshwari. 1974. Palynostratigraphy of the Damuda Group in the Brahmani Coalfield, Rajhamal hills, Bihar. Geophytology 4: 35-45.

Srivastava, S.C., and O.S. Sarate. 1989. Palynostratigraphy of lower Gondwana sediments from Shobhapur block, Patherkhera coalfield, Madhya Pradesh. Palaeobotanist 37: 125-133.

Swetnam, T.W. 1993. Fire history and climate change in giant sequoia groves. Science 262: 885-889.

Ten Haven, H.L., J.W. de Leeuw, J. Rullkötter, and J.S. Sinninghe Damsté. 1987. Restricted utility of the pristane/phytane ratio as a paleoenvironmental indicator. Nature 330: 641-643.

Tiwari, R.S., P. Kumar, and A. Tripathi. 1984. Palynodating of Dubrajpur and Intertrappean beds in subsurface strata of the north eastern Rajmahal Basin. In Vth Indian Geophytological conference, ed. R.S. Tiwari, 207-225. Lucknow: Palaeobotanical Society.

Tiwari, R.S., and A. Tripathi. 1992. Marker assemblage zones of spore and pollen species through Gondwana Palaeozoic and Mesozoic sequence in India. Palaeobotanist 40: 194-236.

Tiwari, R.S., and A. Tripathi. 1995. Palynological assemblages and absolute age relationship of Intertrappean beds in the Rajmahal Basin, India. Cretaceous Research 16: 53-72. 
Tripathi, A. 1997. Palynostratigraphy and palynofacies analysis of subsurface Permian sediments in Talcher coalfield, Orissa. Palaeobotanist 46 (3): 79-88.

Tripathi, A. 2001. Permian, Jurassic and early Cretaceous palynofloral assemblages from subsurface sedimentary rocks in Chuperbhita coalfield, Rajmahal Basin, India. Review of Palaeobotany and Palynology 113: $237-259$

Tripathi, A. 2002. Role of pteridophytic spores in Early Cretaceous stratigraphy and demarcating the Jurassic-Cretaceous Boundary in India. In: Trivedi, P.N. (Ed.). Advances in Pteridology. Pointer Publisher, Jaipur,Rajasthan: pp. 268-279.

Tripathi, A. 2004. Palynology evidences of hitherto unrecognised Jurassic sedimentation in Rajmahal Basin, India. Rivista Italiana di Paleontologia e Stratigrafia 110: 35-42.

Tripathi, A. 2008. Palynochronology of Lower Cretaceous volcanosedimentary succession of the Rajmahalformation in the Rajmahal Basin, India. Cretaceous Research 29: 913-924.

Tripathi, A., B.N. Jana, O. Verma, R.K. Singh, and A.K. Singh. 2013. Early Cretaceous palynomorphs, dinoflagellates and plant mega fossils from the Rajmahal Basin, Jharkhand, India. Journal of Paleontological Society of India 58: 125-134.

Tripathi, A., and A. Ray. 2006. Palynology of the Dubrajpur Formation (Early Triassic to Early Cretaceous) of theRajmahal Basin, India. Palynology 30: 133-149.

Tripathi, A., R.S. Tiwari, and P. Kumar. 1990. Sporae dispersae and their distributional pattern in subsurface Mesozoic sediments of Rajmahal Basin, Bihar, India. Palaeobotanist 37: 367-388.

Uhl, D., A. Jasper, A.M.D. Abu Hamad, and M. Montenari. 2008. Permian and Triassic wildfires and atmospheric oxygen levels. Proceed WSEAS Conferences Special Issues 13: 179-187.

Uhl, D., A. Jasper, T. Schindler, and M. Wuttke. 2010. First evidence of palaeo-wildfire in the early middle Triassic (early Anisian) Voltzia sandstone fossil-Lagerstätte - The oldest post-Permian macroscopic evidence of wildfire discovered so far. Palaios 25: 837-842.

Uhl, D., S. Lausberg, R. Noll, and K.R.G. Stapf. 2004. Wildfires in the Late Paleozoic of Central Europe - Anoverview of the Rotliegend (Upper Carboniferous-Lower Permian) of the Saar-Nahe Basin (SW-Germany). Palaeogeography, Palaeoclimatology, Palaeoecology 207: 23-35.

Uhl, D., M. Wuttke, and A. Jasper. 2020. Woody charcoal with traces of precharring decay from the late Oligocene (Chattian) of Norken (Westerwald, Rhineland-Palatinate, W-Germany). Acta Palaeobotanica 60: 43-50.

Venkatesan, M.I., and J. Dahl. 1989. Organic geochemical evidence for global fires at the Cretaceous/Tertiary boundary. Nature 338: 57-60.

Vishnu-Mittre. 1956. Studies on the fossil flora of Nipania, Rajmahal series, India - Bennettitales. Palaeobotanist 5: 95-99.

Vishnu-Mittre. 1958. Studies on the fossil flora of Nipania, Rajmahal series, India: Pteridophyte and general observations on Nipania fossil flora. Palaeobotanist 7: 47-66.

Vogl, R.J. 1977. Fire: A destructive menace or a natural process. In Symposium on recovery and restoration of damaged ecosystems, ed. J. Cairns, 261-289. Charlottesville, Virginia: University Press of Virginia.

\section{Publisher's Note}

Springer Nature remains neutral with regard to jurisdictional claims in published maps and institutional affiliations.

\section{Submit your manuscript to a SpringerOpen ${ }^{\circ}$ journal and benefit from:}

- Convenient online submission

- Rigorous peer review

- Open access: articles freely available online

High visibility within the field

- Retaining the copyright to your article

Submit your next manuscript at $\boldsymbol{\nabla}$ springeropen.com 